OPEN ACCESS

Edited by:

Peiwen Li,

University of Arizona, United States

Reviewed by:

Miguel A. Laguna-Bercero,

Universidad de Zaragoza, Spain

Kas Hemmes,

Delft University of Technology,

Netherlands

*Correspondence:

Francesco Baldi

francesco.baldi86@gmail.com

Specialty section:

This article was submitted to

Fuel Cells,

a section of the journal

Frontiers in Energy Research

Received: 18 August 2018 Accepted: 03 December 2018

Published: 18 January 2019

Citation:

Baldi F, Wang L, Pérez-Fortes $M$ and Maréchal $F$ (2019) A Cogeneration System Based on Solid Oxide and

Proton Exchange Membrane Fuel Cells With Hybrid Storage for Off-Grid

Applications.

Front. Energy Res. 6:139. doi: 10.3389/fenrg.2018.00139

\section{A Cogeneration System Based on Solid Oxide and Proton Exchange Membrane Fuel Cells With Hybrid Storage for Off-Grid Applications}

\author{
Francesco Baldi ${ }^{1 *}$, Ligang Wang ${ }^{1,2}$, Mar Pérez-Fortes $^{2}$ and François Maréchal ${ }^{1}$ \\ 'Laboratory of Industrial Process and Energy Systems Integration, École Polytechnique Fédérale de Lausanne, Sion, \\ Switzerland, ${ }^{2}$ Group of Energy Materials, École Polytechnique Fédérale de Lausanne, Sion, Switzerland
}

Solid oxide fuel cells (SOFC) have developed to a mature technology, able to achieve electrical efficiencies beyond $60 \%$. This makes them particularly suitable for off-grid applications, where SOFCs can supply both electricity and heat at high efficiency. Concerns related to lifetime, particularly when operated dynamically, and the high investment cost are however still the main obstacles toward a widespread adoption of this technology. In this paper, we propose a hybrid cogeneration system that attempts to overcome these limitations, in which the SOFC mainly provides the baseload of the system. Introducing a purification unit allows the production and storage of pure hydrogen from the SOFC anode off-gas. The hydrogen can be stored, and used in a proton exchange membrane fuel cell (PEMFC) during peak demands. The SOFC system is completed with a battery, used during periods of high electricity production. We propose the use of a mixed integer-linear optimization framework for the sizing of the different components of the system, and particularly for identifying the optimal trade-off between round-trip efficiency and investment cost of the battery-based and hydrogen-based storage systems. The proposed system is applied and optimized to two case studies: an off-grid dwelling, and a cruise ship. The results show that, if the SOFC is used as the main energy conversion technology of the system, the use of hydrogen storage in combination with a PEMFC and a battery is more economically convenient compared to the use of the SOFC in stand-alone mode, or of pure battery storage. The results show that the proposed hybrid storage solution makes it possible to reduce the investment cost of the system, while maintaining the use of the SOFC as the main energy source of the system.

Keywords: SOFC, PEMFC, cogeneration, off-grid energy systems, hybrid system, energy storage

\section{INTRODUCTION}

In this paper, we present a cogeneration system meant for off-grid applications. The proposed system is centered around its main unit, a solid oxide fuel cell (SOFC), that generates electric power and heat. The anode-off gas of the SOFC is upgraded and purified for hydrogen production, which is stored for later use in a proton exchange membrane fuel cell (PEMFC). The main, innovative idea of this work is to include in the system a combination of energy storage in the form of electricity 
(batteries) and hydrogen. This allows the reduction of peak energy demands, thus increasing the average load of the SOFC and decreasing its installed size, and the operation of the SOFC at close to constant load, thus increasing its durability.

\subsection{Background}

As concerns over anthropogenic greenhouse gas (GHG) emissions increase globally, new technical solutions are becoming available to maintain today's life standards while moving toward a more sustainable use of natural resources.

In this context, off-grid applications (i.e., users not connected to a country's main electrical grid) are assuming an increasingly important role in the future energy systems. On the one hand, almost the entire transportation sector (with the exception of trains) can be considered as made of off-grid systems (e.g., cars, trucks, planes and ships). On the other hand, it is expected that nearly half of the communities that today do not have access to electricity will recur to off-grid systems, especially in rural areas (IEA, 2017). More generally, several factors contribute to a renewed interest in small-scale generation. Among them are the cost and public opposition to new transmission lines and large power plants, the need of reducing the vulnerability of the supply chain in centralized systems, and the increased performance of small power technologies (Mandelli et al., 2016).

While a large part of the growth in micro-grid is expected to come from renewable and hybrid systems (IEA, 2017), today still a major part of isolated, off-grid power supply is provided by Diesel generators (IEA, 2017). This is however starting to raise concerns, mostly related to their impact on the environment and to their relatively low conversion efficiency.

\subsection{High-Temperature Fuel Cell Technology}

Because of their high efficiency and low pollutant emissions, fuel cells have become an attractive solution for off-grid and micro-grid applications. The major types of fuel cells are: lowtemperature alkaline fuel cell (AFC), PEMFC, phosphoric acid fuel cell (PAFC), and high-temperature molten carbonate fuel cell (MCFC) and solid-oxide fuel cell (SOFC). All three types of lowtemperature fuel cell technologies are mature and commercial. However, their low operating temperatures (below $100^{\circ} \mathrm{C}$ ) make them unattractive for combined heat and power generation. More importantly, they suffer from water management issues, low fuel flexibility (low $\mathrm{CO}_{2}$ or $\mathrm{CO}$ tolerance and strict $\mathrm{H}_{2}$-purity requirements), and a relatively fast degradation.

High-temperature fuel cells operate at over $600^{\circ} \mathrm{C}$, which provides a higher potential for combined heat and power production, a high fuel flexibility for various gases and liquids (e.g., methane, ethanol, methanol, propane, LPG, diesel, DME, ammonia, and more), and a higher carbon tolerance, with $\mathrm{CO}$ even acting as a potential fuel. SOFCs in particular have demonstrated high efficiency, availability and reliability, and good durability (SOLIDpower, 2017). State-of-the-art SOFC systems provide an electrical efficiency of around $60 \%$ and a CHP system efficiency up to 85-90\% (Gür, 2016). SOFC-GT hybrid system can even achieve electrical efficiencies of as high as $70 \%$ (Buonomano et al., 2015).
Given their high efficiency, low pollutant emissions and high fuel flexibility, SOFCs have been suggested by several authors for their application as power supply to off-grid energy systems. A $1 \mathrm{~kW}$, Diesel-fuelled SOFC was shown to reach a net system efficiency of $45 \%$, higher than any internal combustion engine (ICE) of similar size (Dhingra and Peppley, 2013). Based on the fuel flexibility of SOFC systems, which allows them to also be run on biogas (Van Herle et al., 2004), their use was also suggested in association with the use biogas from biowaste in an off-grid power plant (Cozzolino et al., 2017), and on syngas for an offgrid residential application (Yang et al., 2014). SOFCs were also suggested for application as main and auxiliary power units in road transportation, (Aguiar et al., 2007; Bossel, 2015; Dimitrova and Maréchal, 2017), maritime transport (van Biert et al., 2016) and for aircraft powering (Santarelli et al., 2010; Romeo et al., 2012).

\subsection{Dynamic Response of SOFC-Based Systems}

Degradation and lifetime are among the main challenges for a wider adoption of SOFCs in the market (Yokokawa et al., 2008). Long-term operation of SOFC systems is particularly demanding because of the high level of integration within the system and of its vulnerability against electro-chemical, thermal, and mechanical stresses. Mueller et al. (2007) suggested a list of precautions for limiting cell degradation in SOFC systems. This included, among others, that the operating temperature of the cells should remain within $10 \mathrm{~K}$ of its nominal value, and that the fuel cell voltage should be kept constant to avoid high local heat production rates.

Although lifetime is considered an issue for SOFCs, system duration of $40,000 \mathrm{~h}$ are a reasonable objective for SOFC technology (Tu and Stimming, 2004), and a runtime record of SOFC systems of 10-year continuous operation was recorded (SOLIDpower, 2017). However, most of these results are related to steady-state operations, while there is a rapidly increasing interest in the use of SOFC systems in off-grid applications instead of base load. All of the issues related to fuel cell degradation become more challenging when considering dynamic operating conditions and, in particular, sudden changes in the electrical demand of the system (Bae et al., 2018). This is due to two, main phenomena: load cycling and thermal cycling Hawkes et al. (2009). Load cycling is mainly connected to the variation of fuel utilization, and is hence related to any non-stead state operation of the fuel cell. This can lead, depending to the SOFC type and of the cycle it is subject to, to a degradation of as much as $1 \%$ over 30 cycles (Bujalski et al., 2007). Thermal cycling is mostly connected to system shut-downs, when the system is not expected to generate power for an longer period. While Protonex (2015) announced a portable SOFC of $20 \mathrm{~kW}$ rated power to be used as an off-grid or emergency generator, claiming maintenance intervals exceeding 2,000 h, cycling and start-andstop operations are still recognized as challenging operational conditions for SOFCs (Jacobsen et al., 2013).

Maintaining steady operating conditions during transients is a major challenge in SOFC-based systems operation 
(Fardadi et al., 2016). Of the three main dynamic response characteristics that take place in a SOFC during load-following (electrochemical responses, species concentration and mass flow responses, and thermal responses), the second one is the most critical for cell performance and degradation (Yang et al., 2017). Load transients are often characterized by a larger power demand when compared to steady-state loads (Wu and Gao, 2017), and the probability of failure in SOFC stacks is significantly higher during transients because of the temperature variations involved (Nakajo et al., 2012a,b).

While there is extensive interest in optimal dynamic control of SOFC systems, an alternative approach to increasing the lifetime of SOFC-based systems is based on including other elements in the system that allow reducing the load changes of the fuel cell, both in rate and in magnitude. Batteries are commonly proposed as a way to mitigate load variations and reduce the installed size of the SOFC (Wachsman et al., 2012). The use of batteries (or of other electrical energy storage devices, such as ultra-capacitors; Das and Snyder, 2013) allows for a better dynamic response of the system and for better system economics given that the installed size of the SOFC can be reduced and the average load of the SOFC increased. In the case of vehicles, in addition, it was shown that a combined SOFC-battery power system could provide a significant reduction in the weight of the system (when compared to pure batterypowered vehicles) and in the investment cost (when compared to pure SOFC-powered systems) (Aguiar et al., 2007). These systems have been also proposed for application in off-grid base transceiver stations (Brunaccini et al., 2017). However, systems that only rely on batteries for energy storage have limited capacity due to the high cost, weight and volume of the batteries.

Different alternative systems were proposed in literature to deal with the required dynamic performance in SOFC-based systems. Flywheel were suggested as an alternative to batteries to reduce load-fluctuations for a marine application (Tse et al., 2011). Jia et al. (2015) proposed a SOFC-GT hybrid where the design of the system and the sizing of its components were adapted to improve its overall transient performance, but at the cost of a decrease in system efficiency (Jia et al., 2015). In residential applications, where the system is generally connected to the electric grid, the challenge is generally to follow the heating demand. In these regards, heat storage is often indicated as a potential solution for dealing with load fluctuations and avoiding over-dimensioning of different components of the system (Wakui and Yokoyama, 2014; Yang et al., 2014).

SOFCs can be used to produce a combination of electricity, hydrogen-rich synthesis gas, and high-temperature heat. This makes them particularly suitable both for stand-alone applications and integrated with other thermal cycles or energy conversion technologies (Zhang et al., 2010). An example of this approach is proposed by Obara (2010), who suggests to exploit the waste heat from a SOFC in a reformer to generate hydrogen to be used as fuel for a PEMFC, with the introduction of a heat storage system to allow for a better handling of load fluctuations. This allows not only the integration of the reforming of the natural gas, but also the ability to shift it in time with respect to the operations of SOFC, which act as the source of waste heat for the reforming reaction.

\subsection{Hybrid SOFC-PEMFC Systems}

More generally, several authors have suggested to exploit the flexibility of SOFC systems for the combined production of electric power and hydrogen. Perdikaris et al. (2010) proposed a system for the production of electricity, heat and hydrogen that could be operated in two modes: one for power generation, and one for hydrogen generation. The concept, involving the coupling of a SOFC and a SOEC as separate units, proved quite challenging to control. Becker et al. (2012) introduced instead the concept of purifying the anode off-gas of a SOFC to produce hydrogen as a useful system output, achieving close to $70 \%$ efficiency in the combined generation of power and hydrogen, and over $85 \%$ efficiency when waste heat was also accounted. Similar results were obtained by Leal and Brouwer (2005), who also showed that internal reforming is more appropriate for this types of systems, if estimated based on first-law efficiencies. The co-production of electricity and hydrogen based on a SOFC was also simulated by Shaffer and Brouwer (2014) based on real data for the demand of a commercial building, using a 2-D model that allowed investigating the effect of a highly-dynamic load on the internal properties of the fuel cell. Hemmes et al. (2008) simulated these systems in detail, for different types of operational modes, showing that these systems can be operated flexibly, i.e., varying the share of electric and hydrogen power. Pérez-Fortes et al. (2018) proposed the design of an SOFCbased co-production system for electricity and hydrogen, based on the multi-stage optimization procedure proposed by Mian et al. (2016), thus achieving a combined efficiency above 65\% (excluding waste heat) that is maintained over a wide range of combinations of hydrogen and power generation.

Hydrogen can be used as fuel for other units. The combination of a SOFC with a proton exchange membrane (PEMFC) system was first introduced by Vollmar et al. (2000). The integration of a hydrogen purification unit downstream of the SOFC allows operating the cells at a lower fuel utilization rate, thus resulting in a lower Nernst loss. This allows for a higher overall efficiency of the system, as the hydrogen not converted in the cell is recovered and used in the PEMFC downstream. In addition, using the hydrogen that leaves the SOFC stacks in a fuel cell, instead of a burner, improves the overall efficiency of the system. This consideration is based on the assumption of using exergy to measure the combined quality and quantity of energy, according to which hydrogen is more valuable than waste heat regardless of the temperature (Kotas, 2013).

Initial results based on simulations showed that SOFCPEMFC hybrid systems can reach $61 \%$ net electric efficiency (Dicks et al., 2000; Tan et al., 2016) and overall efficiency up to 90\% (Subramanyan et al., 2004; Tan et al., 2016), a significantly higher value compared to a reformer-PEMFC system and and to the early stand-alone SOFC systems (efficiency of around $50 \%)$. In addition, the initial estimations presented by Dicks et al. (2000) for the capital cost of the system suggested that the SOFC-PEMFC hybrid system can have a better economic performance compared to other systems of similar power output 
(Dicks et al., 2000). Similar results where obtained in the work of Yokoo and co-workers (Yokoo and Take, 2004; Yokoo et al., 2006, 2007), who showed that the electrical efficiency of a hybrid SOFC-PEMFC can be up to $5 \%$ higher than that of a standalone SOFC system, a value that is comparable to SOFC-GT systems. Compared to the latter, the SOFC-PEMFC hybrid has the characteristic, typical of fuel cells, of an electric efficiency that does not depend on the size and on the load on the system.

To the best of our knowledge, however, the use of SOFCPEMFC systems, where the hydrogen purified from the anode gas flow of a SOFC is used as storage medium and, hence, allows to decouple the power generation of the SOFC and the PEMFC, has not yet been studied. This strategy would allow reducing the investment cost of the system, given the lower cost per kWh of hydrogen tanks compared to batteries, while maintaining a high system efficiency.

\subsection{Aim}

In this paper, we present a cogeneration system based on a SOFC as the main energy conversion technology. The separation and purification of the hydrogen from the anode off-gas of the SOFC allows for its temporary storage, and for its use in a dedicated PEMFC during peaks of electric power demand. The system can also include the installation of batteries, that provide energy storage capacity at higher efficiency (but also higher cost) than hydrogen storage. We propose the use of a mixed integerlinear programming (MILP) approach to optimize the size of the different components of the system with the total annualized cost as the objective to minimize. The proposed system is applied to two potential off-grid applications: an isolated dwelling, and a cruise ship.

\section{DESCRIPTION OF THE SOFC-BASED POWER SYSTEM}

The proposed system is based on the use of a SOFC as the main energy source of the polygeneration system. As SOFCs are not suitable to handle large and fast load changes, we included in the design other systems more suitable for load following. The core of the proposed system is composed by (Figure 1):

- A SOFC, equipped with a hydrogen purification system, as the main energy source of the system

- A battery for fast transients and peak shaving

- A hydrogen storage system combined with a PEMFC for medium-slow load transients

The hybrid SOFC (H-SOFC) is the main unit of the system and is able to generate both electrical power and waste heat for cogeneration purposes. In this paper we assume the use of the system structure proposed by Pérez-Fortes et al. (2018), where the composition of the anode off-gas of the SOFC is adapted first by a two-stage water-gas shift (WGS) reactor to enhance the hydrogen content, and then by a pressure swing absorption (PSA) unit for achieving high $\mathrm{H}_{2}$ purity. The purified hydrogen flow from the PSA is sent to the hydrogen storage tanks. The unreacted gas after the PSA is combusted and the generated heat is utilized within the system and for direct satisfaction of heat load. Part of the inlet natural gas flow can also be sent to the burner, depending on the operational conditions, to ensure the heat balance of the system. The system can operate in a wide range of combinations of electric power and hydrogen output. In addition to the electric power and hydrogen output, the H-SOFC also provides waste heat for cogeneration purposes, resulting from the intermediate cooling of the anode gas between the two WGS reactors $\left(\dot{Q}_{\mathrm{H}-\mathrm{SOFC}, \mathrm{WGS}}\right)$ and from the cooling of the burner exhaust gas ( $\dot{Q}_{\mathrm{H}-\mathrm{SOFC}, \mathrm{WGS}}$ ).

In order to reduce load fluctuations and the installed size of the SOFC, the proposed system is also equipped with a PEMFC. PEMFCs operate at much lower temperatures compared to SOFCs and are, hence, more flexible in terms of load change (Nguyen et al., 2016; van Biert et al., 2016). The PEMFC is fuelled using the hydrogen generated by the SOFC. In this work, we propose the use of high temperature PEMFCs because of their better suitability to cogeneration purposes and of their higher tolerance of carbon monoxide impurities in the feed gas (Nguyen et al., 2016; van Biert et al., 2016). For the same purpose, the proposed system is also equipped with an electric energy storage device. While many types of EES could serve the purpose, in this paper we focus on the use of batteries, and particularly of lithiumion technology, that are becoming increasingly common for both mobile and stationary applications (Dunn et al., 2011; Nykvist and Nilsson, 2015).

\section{OPTIMIZATION PROBLEM DEFINITION}

In the previous section, we described the main features of the proposed cogeneration system based on a SOFC with hybrid energy storage for off-grid applications. The specifics of the system, and more specifically the sizes of its different units, are not fixed and should be defined based on the characteristic of the specific case the system is applied to.

For this reason, in this paper we approach the problem of the sizing of the system as a MILP problem and solve it using the OSMOSE framework, specifically developed for the solution of MILP-based energy integration problems (Kantor et al., under review), with the total annualized cost (Equation 1) as the objective to minimize. The size of each component of the power plant ( $\mathrm{H}$-SOFC, PEMFC, $\mathrm{H}_{2}$ storage, batteries, case-specific components) are the decision variables of interest for the problem. The energy and mass streams for each component at each time step also appear in the optimization as decision variables. The MILP approach was selected based on the high reliability and speed of available solvers. The proposed system and optimization are then applied to two case studies, an off-grid dwelling and a cruise ship, described in section 4 .

The objective function $\left(f_{\text {obj }}\right)$ of the optimization problem is defined in Equation (1).

$$
f_{\text {obj }}=C_{\text {op }}+C_{\text {inv, act }}
$$




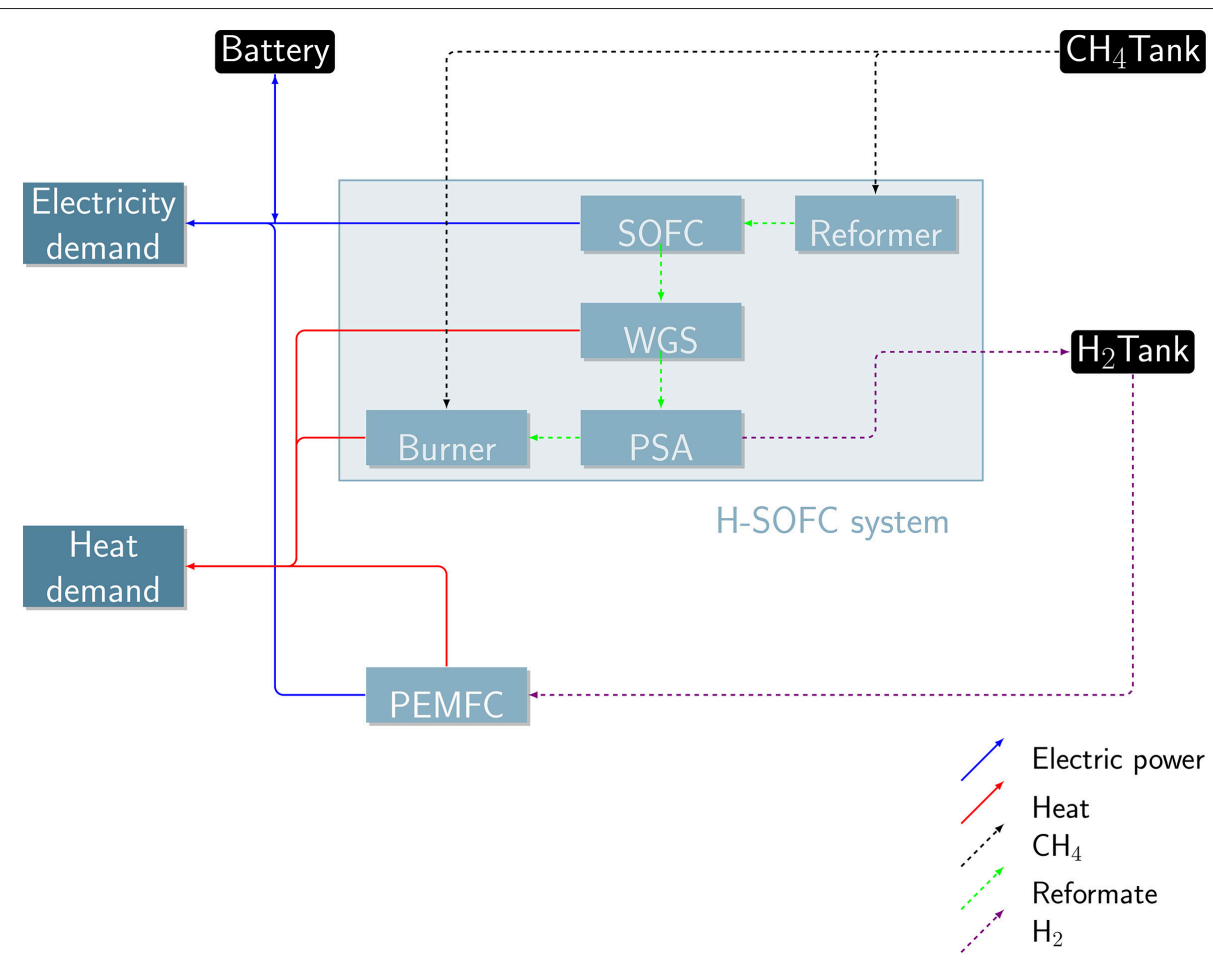

FIGURE 1 | Graphical representation of the proposed energy system.

Where the operational cost $\left(C_{\mathrm{op}}\right)$ and the annualized investment cost $\left(C_{\text {inv,act }}\right)$ are defined as:

$$
\begin{aligned}
C_{\mathrm{op}} & =\sum_{u \in \mathbb{U}} \sum_{t \in \mathbb{T}} f_{\mathrm{u}, \mathrm{t}}^{\prime} C_{\text {fuel }} \dot{E}_{\text {fuel,u }}^{\max } \Delta t_{\mathrm{t}} \xi_{\mathrm{t}} \\
C_{\text {inv,act }} & =\sum_{u \in \mathbb{U}} \frac{C_{\mathrm{u}}^{\mathrm{inv}, \mathrm{fix}} \boldsymbol{y}_{\mathrm{u}}+\boldsymbol{f}_{\mathrm{u}} C_{\mathrm{u}}^{\mathrm{inv}, \mathrm{var}} \dot{E}_{\text {size }, \mathrm{u}}^{\max }}{\frac{(i+1)^{N_{\mathrm{u}}^{\mathrm{y}}-1}}{i(1+i)^{N_{\mathrm{u}}^{y}}}}
\end{aligned}
$$

where the problem parameters in the equations above are: the fuel cost $\left(C_{\text {fuel }}\right)$, the maximum fuel consumption of each utility $u\left(\dot{E}_{\text {fuel,u }}^{\max }\right)$, the duration of each time step $\left(\Delta t_{t}\right)$, the number of occurrences of each time step during the year of reference $\left(\xi_{t}\right.$, see later in the text for more details), the fixed (i.e., size-independent) and variable (i.e., size-dependent) investment cost of each utility $\left(C_{\mathrm{u}}^{\text {inv,fix }}\right.$ and $\left.C_{\mathrm{u}}^{\text {inv,var }}\right)$, the maximum energy/material flow used for sizing purposes of each utility $u\left(\dot{E}_{\text {size,u }}^{\max }\right)$, the lifetime of each utility $\left(N_{\mathrm{u}}^{\mathrm{y}}\right)$, and the interest rate $(i) . \mathbb{U}$ and $\mathbb{T}$ represent the set of utilities and of time steps included in the problem, respectively.

The problem variables to be optimized are: the load of each utility $u$ at each time step $t$ with respect to its maximum installed power $\left[\boldsymbol{f}^{\prime}(\boldsymbol{u}, \boldsymbol{t})\right.$, ranges between 0 and 1$]$; the sizing of each utility with respect to its maximum installed power $[\boldsymbol{f}(\boldsymbol{u})$, also ranges between 0 and 1]; the on-off decision of each utility for each time step $\left[\boldsymbol{y}^{\prime}(\boldsymbol{u}, \boldsymbol{t})\right.$, binary]; and the installation decision for each utility $[\boldsymbol{y}(\boldsymbol{u})$, also binary]. The aforementioned variables are related by the following constraints:

$$
\begin{array}{ll}
f_{\mathrm{u}, \mathrm{t}}^{\prime} \leq f_{\mathrm{u}} & \forall t \text { in } \mathbb{T}, \text { u in } \mathbb{U} \\
f_{\mathrm{u}, \mathrm{t}}^{\prime} \leq \boldsymbol{y}_{\mathrm{u}, \mathrm{t}}^{\prime} & \forall t \text { in } \mathbb{T}, \text { in } \mathbb{U} \\
y_{\mathrm{u}, \mathrm{t}}^{\prime} \leq y_{\mathrm{u}} & \forall t \text { in } \mathbb{T}, \text { u in } \mathbb{U}
\end{array}
$$

where Equation (4) represents the fact that a utility cannot operate at a higher load than the maximum installed size, Equation (5) that a utility can only have a non-zero load if it is turned on, and Equation (6) that a utility can only be used if it is installed.

The optimization problem is further constrained by the fact that energy and material balances must be respected at all times:

$$
\sum_{u \in \mathbb{U}} f_{\mathrm{u}, \mathrm{t}}^{\prime} \dot{E}_{\mathrm{l}, \mathrm{u}}^{\mathrm{max}}+\sum_{p \in \mathbb{P}} \dot{E}_{\mathrm{l}, \mathrm{p}, \mathrm{t}}=0 \quad \forall t \text { in } \mathbb{T}, \text { lin } \mathbb{L}
$$

where $\dot{E}_{1, \mathrm{u}}^{\max }$ represents the maximum value of the net energy/material flow $l$ for unit $u$, and $\dot{E}_{1, \mathrm{p}, \mathrm{t}}$ represents the constant energy/material flow $l$ at time step $t$ of the process $p$, typically representing the energy demand of the system.

To achieve a good accuracy of the description of the variability of the demand while avoiding excessive computational demand on the solver, we used the concept of typical periods to model the energy demand and the ambient conditions of the system (Fazlollahi et al., 2014). The notion of typical periods is based on the assumption that the yearly demand of a generic energy 
system can be represented by a limited set of periods, where the term period can refer to a day, a week, or a voyage, defined by a sequence of time steps. The problem is hence defined by $N_{\mathrm{t}}$ time steps, which are sub-divided among $N_{\text {tp }}$ typical periods. The total duration of yearly operations is then reconstructed as:

$$
\sum_{\mathrm{t} \in \mathbb{T}} \Delta t_{\mathrm{t}} \xi_{\mathrm{t}}=8760
$$

where every $\Delta t_{\mathrm{t}}$ has an assigned value for $\xi_{\mathrm{t}}$, which represents how many times during a year the corresponding typical period is expected to occur. In each problem there are only $N_{\text {tp }}$ different values for $\xi_{\mathrm{t}}$, and the value of $\xi_{\mathrm{t}}$ is the same for all time steps $t$ belonging to the same typical period.

The case of heat is treated differently, in order to simultaneously account for the first and second law of thermodynamics, by using the concept of heat cascade (Linhoff et al., 1982):

$$
\sum_{u \in \mathbb{U}} f_{\mathrm{u}, \mathrm{t}}^{\prime} \dot{Q}_{\mathrm{k}, \mathrm{u}}^{\mathrm{max}}+\sum_{p \in \mathbb{P}} \dot{Q}_{\mathrm{k}, \mathrm{p}, \mathrm{t}}+R_{k+1}-R_{k}=0 \quad \forall t \text { in } \mathbb{T}, k \text { in } \mathbb{K}
$$

with:

$$
\begin{aligned}
& R_{\mathrm{k}} \leq 0 \\
& R_{1}=0, R_{\mathrm{N}_{\mathrm{k}+1}}=0
\end{aligned} \quad \forall k \text { in } \mathbb{K}
$$

where the $R_{\mathrm{k}}$ represents the energy cascaded form the temperature interval $k$ to the lower temperature intervals, and $\mathbb{K}$ represents the set of temperature intervals of the heat cascade. $\dot{Q}_{\mathrm{k}, \mathrm{u}, \mathrm{t}}^{\max }$ is defined as the sum of the maximum contributions of all heat streams $s$ of unit $u$ in the temperature interval $k$ and $\dot{Q}_{\mathrm{k}, \mathrm{p}, \mathrm{t}}$ as the sum of the contributions of all heat streams $s$ of process $p$ in temperature interval $k$ at time step $t$ :

$$
\begin{aligned}
\dot{Q}_{\mathrm{k}, \mathrm{u}}^{\max } & =\sum_{s \in \mathbb{S}_{u}} \dot{Q}_{\mathrm{k}, \mathrm{s}, \mathrm{u}}^{\max } \\
\dot{Q}_{\mathrm{k}, \mathrm{p}, \mathrm{t}} & =\sum_{s \in \mathbb{S}_{p}} \dot{Q}_{\mathrm{k}, \mathrm{s}, \mathrm{p}, \mathrm{t}}
\end{aligned}
$$

It should be noted that the heat cascade as defined in Equation (9) is valid only for all units that are allowed to exchange heat with each other. Depending on the specific case, some units might not be in conditions of directly exchanging heat (e.g., because of logistic, economic, or safety constraints). In this case, one heat cascade is defined for each group of units that are allowed to exchange heat with each other.

In both case studies, additional conventional technologies (such as gas engines and boilers) are introduced in the optimization problem as a potential solution to cover the peak demand. However, as the main objective of this work was to dimension a system that uses an SOFC as the main energy conversion unit, we included a constraint forcing that a certain fraction $\phi$ of the total fuel input to the system is used in the SOFC:

$$
\text { s.t. } \sum_{t \in \mathbb{T}} f_{\mathrm{SOFC}, \mathrm{t}}^{\prime} \dot{E}_{f u e l, H-S O F C}^{\max } \Delta t_{\mathrm{t}} \geq \phi \sum_{u \in \mathbb{U}} \sum_{t \in \mathbb{T}} f_{\mathrm{u}, \mathrm{t}}^{\prime} \dot{E}_{f u e l, u}^{\max } \Delta t_{\mathrm{t}}
$$

In order to improve the feasibility of the resulting optimal solution, we also included a constraint related to the maximum system weight, which is often considered a limitation in transportation applications. This contraint is expressed by Equation (15).

$$
\sum_{u \in \mathbb{U}} \tilde{p}_{\mathrm{u}}^{-1} f_{\mathrm{u}} P_{\max }(u) \leq m^{\max }
$$

where $\tilde{p_{\mathrm{u}}}$ represents the power-to-weight ratio of the utility $u$.

In addition to the problem-level equations, each unit is defined by additional constraints. The general form of the different energy streams of a generic unit is given by Equation (7). As energy conversion units are generally defined by the efficiency of the conversion process, in this formulation this is given by:

$$
\eta_{1, \mathrm{u}}=\frac{\dot{E}_{1, \mathrm{u}}^{\max }}{\dot{E}_{\text {fuel,u }}^{\max }}
$$

The case of the hybrid SOFC fuel cell represents an exception. In this cases, we wanted to model the fact that the efficiency of the component depends on a combination of the power and hydrogen generation loads. This was done by considering the unit "H-SOFC" as being made of two sub-units, the "Power-generation" (H-SOFC $\left.C_{P}\right)$ and the "Hydrogen generation" $\left(\mathrm{H}-\mathrm{SOFC}_{H}\right)$, each being defined by its own, independent sizing variable $\left(f_{\mathrm{H}-\mathrm{SOFC}}\right.$ and $f_{\mathrm{H}-\mathrm{SOFC}_{\mathrm{H}}}$, respectively). The consumption of natural gas and the exhaust heat streams are consequently defined using Equation (17), where the $\boldsymbol{f}_{\mathrm{u}, \mathrm{t}}^{\prime}$ of each of the streams is connected to the ones of the $\mathrm{H}_{-}-\mathrm{SOFC}_{P}$ and $\mathrm{H}-\mathrm{SOFC}_{H}$ with the following relationship:

$$
\begin{aligned}
\dot{E}_{\mathrm{NG}, \mathrm{H}-\mathrm{SOFC}_{\mathrm{M}}, \mathrm{t}} & =\dot{E}_{\mathrm{NG}, \mathrm{H}-\mathrm{SOFC}_{\mathrm{M}}}^{\mathrm{max}} f_{\mathrm{H}-\mathrm{SOFC}_{\mathrm{M}}, \mathrm{t}}^{\prime} \\
& =\dot{E}_{\mathrm{NG}, \mathrm{H}-\mathrm{SOFC}_{\mathrm{M}}}^{\mathrm{max}} f_{\mathrm{H}-\mathrm{SOFC}_{\mathrm{P}} \mathrm{t}}^{\prime}+w_{H} f_{\mathrm{H}-\mathrm{SOFC}_{\mathrm{H}}, \mathrm{t}}^{\prime}
\end{aligned}
$$

The principle of 17 also applies to the waste heat flows from the H-SOFC: the heat recovery from the water gas shift $\left(\dot{Q}_{\mathrm{H}-\mathrm{SOFC}, \mathrm{WGS}}\right)$ and the heat recovery from the anode off-gas $\left(\dot{Q}_{\mathrm{H}-\mathrm{SOFC}, \mathrm{EG}}\right)$ :

$$
\begin{aligned}
& \dot{Q}_{\mathrm{WGS}, \mathrm{H}-\mathrm{SOFC}_{\mathrm{M}}, \mathrm{t}}=\dot{Q}_{\mathrm{WGS}, \mathrm{H}-\mathrm{SOFC}_{\mathrm{M}}}^{\max } f_{\mathrm{H}-\mathrm{SOFC}_{\mathrm{P}}, \mathrm{t}}^{\prime}+w_{\mathrm{WGS}} f_{\mathrm{H}-\mathrm{SOFC}_{\mathrm{H}}, \mathrm{t}}^{\prime} \\
& \dot{Q}_{\mathrm{EG}, \mathrm{H}-\mathrm{SOFC}_{\mathrm{M}}, \mathrm{t}}=\dot{Q}_{\mathrm{EG}, \mathrm{H}-\mathrm{SOFC}_{\mathrm{M}}}^{\max } f_{\mathrm{H}-\mathrm{SOFC}, \mathrm{t}}^{\prime}+w_{\mathrm{EG}} f_{\mathrm{H}-\mathrm{SOFC}, \mathrm{t}}^{\prime}
\end{aligned}
$$

This results in the H-SOFC having time-dependent efficiencies expressed by the following relations:

$$
\begin{aligned}
& \eta_{\mathrm{el}+\mathrm{H}_{2}, \mathrm{H}-\mathrm{SOFC}}=\frac{\dot{E}_{\mathrm{el}, \mathrm{H}-\mathrm{SOFC}_{\mathrm{P}}}^{\max } f_{\mathrm{H}-\mathrm{SOFC}_{\mathrm{P}} \mathrm{t}}^{\prime}+\dot{E}_{\mathrm{H}_{2}, \mathrm{H}-\mathrm{SOFC}_{\mathrm{H}}}^{\max } f_{\mathrm{H}-\mathrm{SOFC}_{\mathrm{H}}, \mathrm{t}}^{\prime}}{\dot{E}_{\mathrm{NG}, \mathrm{H}-\mathrm{SOFC}_{\mathrm{M}}}^{\max }\left(f_{\mathrm{H}-\mathrm{SOFC} \mathrm{P}, \mathrm{t}}^{\prime}+w_{\mathrm{H}} f_{\mathrm{H}-\mathrm{SOFC}_{\mathrm{H}}, \mathrm{t}}^{\prime}\right)} \\
& \eta_{\mathrm{WGS}, \mathrm{H}-\mathrm{SOFC}}=\frac{\dot{Q}_{\mathrm{WGS}, \mathrm{H}-\mathrm{SOFC}_{\mathrm{M}}}^{\max }\left(f_{\mathrm{H}-\mathrm{SOFC}_{\mathrm{P}, \mathrm{t}}}^{\prime}+w_{W G S} f_{\mathrm{H}-\mathrm{SOFC}_{\mathrm{H}, \mathrm{t}}}^{\prime}\right)}{\dot{E}_{\mathrm{NG}, \mathrm{H}-\mathrm{SOFC}_{\mathrm{M}}}^{\max }\left(f_{\mathrm{H}-\mathrm{SOFC}, \mathrm{t}}^{\prime}+w_{H} f_{\mathrm{H}-\mathrm{SOFC}_{\mathrm{H}, \mathrm{t}}}^{\prime}\right)} \\
& \eta_{\mathrm{EG}, \mathrm{H}-\mathrm{SOFC}}=\frac{\dot{Q}_{\mathrm{EG}, \mathrm{H}-\mathrm{SOFC}_{\mathrm{M}}}^{\max }\left(f_{\mathrm{H}-\mathrm{SOFC}_{\mathrm{P}} \mathrm{t}}^{\prime}+w_{E G} f_{\mathrm{H}-\mathrm{SOFC}_{\mathrm{H}, \mathrm{t}}}^{\prime}\right)}{\dot{E}_{\mathrm{NG}, \mathrm{H}-\mathrm{SOFC}_{\mathrm{M}}}^{\max }\left(f_{\mathrm{H}-\mathrm{SOFC}_{\mathrm{P}, \mathrm{t}}}^{\prime}+w_{H} f_{\mathrm{H}-\mathrm{SOFC}_{\mathrm{H}, \mathrm{t}}}^{\prime}\right)}
\end{aligned}
$$


The values of $\dot{E}_{\mathrm{NG}, \mathrm{H}-\mathrm{SOFC}_{\mathrm{M}}}^{\max }, \dot{Q}_{\mathrm{WGS}, \mathrm{H}-\mathrm{SOFC}_{\mathrm{M}}}^{\max }, \dot{Q}_{\mathrm{EG}, \mathrm{H}-\mathrm{SOFC}_{\mathrm{M}}}^{\max }, w_{H}$, $w_{\mathrm{WGS}}$, and $w_{\mathrm{EG}}$ were calibrated based on the performance of the hybrid SOFC system as described in Pérez-Fortes et al. (2018) as to minimize the error between the energy flows reported in the cited source and the ones resulting out of the proposed linear modeling. This results in the total efficiency of the system (based on power and hydrogen production) to range between 64.7 and $66.4 \%$ depending on the operational condition, while the corresponding efficiencies for the waste heat in the exhaust gas and the WGS reactor are [0.12-0.14] and [0.17-0.19], respectively.

As one of the two main rationales for the expected advantage of the proposed system is related to its ability of overcoming the limited dynamic performance of SOFCs, we implemented a constraint related to the ability of the SOFC system to change load between consecutive time steps. Referring to a generic utility $u$, this is included in the problem as follows:

$$
\begin{aligned}
f_{\mathrm{u}, \mathrm{t}}^{\prime}-f_{\mathrm{u}, \mathrm{t}-1}^{\prime} & \leq \Delta \lambda_{\mathrm{u}}^{\max } \\
f_{\mathrm{u}, \mathrm{t}-1}^{\prime}-f_{\mathrm{u}, \mathrm{t}-1}^{\prime} & \geq-\Delta \lambda_{\mathrm{u}}^{\max }
\end{aligned}
$$

The problem definition also includes two different types of energy storage: a battery, and a hydrogen tank. These are modeled with a state variable indicating the current state of charge of the storage, that is calculated for each time step in accordance to the following definition:

$$
\Delta E_{\mathrm{u}, \mathrm{t}}=\left(\dot{E} \max _{\mathrm{u}} f_{\mathrm{u}(\text { cha }), \mathrm{t}}^{\prime}-\dot{E} \max _{\mathrm{u}} f_{\mathrm{u}(\text { dis }), \mathrm{t}}^{\prime}\right) \Delta_{t_{\mathrm{t}}}
$$

where the subscripts (dis) and (cha) refer to the discharge and charge processes. It should be noted that, to preserve the overall energy balance, it is here assumed that the state of charge of the energy storage must be the same at the start and at the end of each typical period.

Both types of storage may involve losses in the chargingdischarging cycles. These are accounted through an electric energy flow, representing charge/discharge losses in the battery and compression power demand in the hydrogen storage system:

$$
\dot{E}_{\mathrm{u}, \mathrm{t}}^{\mathrm{loss}}=\dot{E}_{\mathrm{u}}^{\mathrm{max}} f_{\mathrm{u}(\mathrm{cha}), \mathrm{t}}^{\prime}\left(\frac{1}{\eta_{\mathrm{u}}^{\text {cha }}}-1\right)+\dot{E}_{\mathrm{u}}^{\mathrm{max}} f_{\mathrm{u}(\mathrm{dis}), \mathrm{t}}^{\prime}\left(1-\eta_{\mathrm{u}}^{\mathrm{dis}}\right)
$$

\section{CASE STUDIES}

In this paper, the optimization of the proposed system was applied to two case studies: an off-grid dwelling, and a cruise ship. The case studies were chosen based on the availability of data for the energy demand, and of their relevance as potential applications of the proposed system. A detailed description of the values employed for the different stream parameters used in the models is provided in Table 2. Cost factors used for the calculation of the investment costs are described in detail in Appendix A and in Table 1. The values used for the energy demand of the two case studies are provided in tabular form in the Supplementary Material.

\subsection{Off-Grid Dwelling}

The case study for an off-grid dwelling is based on a reference single residential unit of $200 \mathrm{~m}^{2}$ located in the North of Italy (Bianchi et al., 2013, 2014). The house has a declared overall demand of 3 MWh electric energy, 20 MWh heating, 3 MWh hot water heating, and $1 \mathrm{MWh}$ cooling. The yearly energy demand is simulated using days as typical periods, each made of 24 one-hour time steps. In this case, we chose to represent yearly operations with 4 typical days:

\begin{tabular}{|c|c|c|c|}
\hline Parameter name & unit & House & Ship \\
\hline \multicolumn{4}{|c|}{ Problem parameters } \\
\hline Interest rate & - & \multicolumn{2}{|c|}{0.05} \\
\hline Fuel cost & EUR/kWh & 0.08 & 0.045 \\
\hline \multicolumn{4}{|c|}{ H-SOFC (Pérez-Fortes et al., 2018) } \\
\hline$\dot{E}_{\mathrm{NG}, \mathrm{H}-\mathrm{SOFC}}$ & $\mathrm{kW}$ & \multicolumn{2}{|c|}{34.2} \\
\hline$\dot{Q}_{W G S, H-S O F C_{M}}^{\max }$ & $\mathrm{kW}$ & \multicolumn{2}{|c|}{6.43} \\
\hline$\dot{Q}_{\mathrm{EG}, \mathrm{H}-\mathrm{SOF}}^{\max } \mathrm{S}_{\mathrm{M}}$ & $\mathrm{kW}$ & \multicolumn{2}{|c|}{3.87} \\
\hline$w_{\mathrm{H}, \mathrm{H}-\mathrm{SOFC}}$ & - & \multicolumn{2}{|c|}{1.295} \\
\hline$w_{W G S, H-S O F C}$ & - & \multicolumn{2}{|c|}{0.273} \\
\hline$w_{E G, H-S O F C}$ & - & \multicolumn{2}{|c|}{1.13} \\
\hline$T_{\text {WGS,H-SOFC }}$ & $\mathrm{K}$ & \multicolumn{2}{|c|}{ 363(in), 298(out) } \\
\hline \multicolumn{2}{|c|}{ PEMFC (Arsalis et al., 2011) } & \multicolumn{2}{|c|}{ 383(in), 298(out) } \\
\hline$\eta_{\mathrm{el}, \mathrm{PEMFC}}$ & - & \multicolumn{2}{|c|}{0.53} \\
\hline$\eta_{\text {th,PEMFC }}$ & - & \multicolumn{2}{|c|}{0.12} \\
\hline $\begin{array}{l}T_{\text {EG,PEMFC }} \\
\text { Battery (Adametz }\end{array}$ & \multicolumn{3}{|c|}{ Battery (Adametz et al., 2017) } \\
\hline$\eta_{\text {batt,cha }}$ & - & \multicolumn{2}{|c|}{0.88} \\
\hline $\begin{array}{l}\eta_{\text {batt,dis }} \\
\quad \text { Hydrogen tank (G }\end{array}$ & - & \multicolumn{2}{|c|}{0.93} \\
\hline$\eta_{\mathrm{H}_{2} \text { tank,cha }}$ & - & 1 & 0.93 \\
\hline \multicolumn{2}{|c|}{ High Speed Diesel engine (MTU, 2017) } & \multicolumn{2}{|c|}{1} \\
\hline$\eta_{\text {mech,ICE }}$ & - & & 0.35 \\
\hline$\eta_{\mathrm{EG}, \mathrm{ICE}}$ & - & & 0.27 \\
\hline$\eta_{\mathrm{HTC}, \mathrm{ICE}}$ & - & & 0.16 \\
\hline$\eta_{\mathrm{LTC}, \mathrm{ICE}}$ & - & & 0.13 \\
\hline$T_{\mathrm{EG}, \mathrm{ICE}}$ & K & & 603(in), 423(out) \\
\hline$T_{\text {HTC,ICE }}$ & K & & 363(in), 353(out) \\
\hline$T_{\text {LTC,ICE }}$ & K & & 323(in), 313(out) \\
\hline \multicolumn{4}{|c|}{ Gas boiler [House: Rager (2015), Ship: Cohen and Fritz (1962)] } \\
\hline$\eta_{\mathrm{EG}, \mathrm{GB}}$ & - & 0.95 & 0.85 \\
\hline$T_{\mathrm{EG}, \mathrm{GB}}$ & $\mathrm{K}$ & 1,073(in), 353(out) & 1073(in), 393(out) \\
\hline \multicolumn{4}{|c|}{ Heat pump (Henchoz, 2016) } \\
\hline$\varepsilon \mathrm{HP}$ & - & \multicolumn{2}{|c|}{0.5} \\
\hline$T_{\text {cond,HP }}$ & $\mathrm{K}$ & 323 & 378 \\
\hline \multicolumn{4}{|c|}{ Refrigeration unit (Henchoz, 2016) } \\
\hline$\varepsilon_{\mathrm{REF}}$ & - & 0.5 & \\
\hline$T_{\text {evap,REF }}$ & K & 278 & \\
\hline \multicolumn{4}{|c|}{ PV solar panels (WES, 2016) } \\
\hline$\eta_{\mathrm{el}, \mathrm{PV}}$ & - & 0.15 & \\
\hline
\end{tabular}

- Winter $\left(\xi_{1-24}=122\right)$

- Mid-season (C) $\left(\xi_{25-48}=76\right)$

TABLE 1 | Stream definition for each unit in the problem. 
TABLE 2 | Cost coefficients and expected lifetime for the investigated utilities.

\begin{tabular}{|c|c|c|c|c|}
\hline Utility name & Source & Fixed inv. cost [kEUR] & $\begin{array}{c}\text { Size-dependent } \\
\text { inv.cost [kEUR/kW] }\end{array}$ & Lifetime [y] \\
\hline SOFC - H2gen & Becker et al., 2012; BMI, 2016 & 0 & 2.2 & 6 \\
\hline PEMFC & BMI, 2016 & 0 & 1.6 & 8 \\
\hline HS Gas engine & Trivyza et al., 2018 & 0 & 0.575 & 20 \\
\hline Gas boiler $(\mathrm{H})$ & NERA and AEA, 2009 & 0.5 & 0.1 & 20 \\
\hline Gas boiler (S) & NERA and AEA, 2009 & 50 & 0.054 & 20 \\
\hline Heat pump $(H)$ & NERA and AEA, 2009 & 0.5 & 0.6 & 20 \\
\hline Heat pump (S) & NERA and AEA, 2009 & 50 & 0.5 & 20 \\
\hline Hydrogen storage & Al-Sharafi et al., 2017 & 0 & 0.045 & 20 \\
\hline Battery & Nykvist and Nilsson, 2015 & 0 & 0.30 & 6 \\
\hline PV & Suciu et al., 2018 & 0 & 0.247 & 20 \\
\hline
\end{tabular}

- Mid-season $(\mathrm{H})\left(\xi_{49-72}=76\right)$

- $\operatorname{Summer}\left(\xi_{73-96}=91\right)$

where the hot mid-season $(\mathrm{H})$ has no space heating demand, and a reduced cooling demand (compared to the summer season), while the cold mid-season (C) is characterized by no cooling demand, and by a reduced heating demand (compared to the winter season). Electric and hot water heating power demand are considered not to be influenced by the season. The four energy demands are graphically represented in Figure 2.

In addition to the 4 typical days, two "extreme days" were defined and used in the optimization, with the main function of ensuring that the sizing of the components can account for particularly challenging operational conditions. The winter extreme day is based on the typical winter day, with a $50 \%$ higher demand of heating and hot water, a 20\% higher electricity demand and $10 \mathrm{~K}$ lower ambient temperature. The summer extreme day is based on the typical summer day, with 50\% higher cooling and hot water demand, 20\% higher electricity demand, and $10 \mathrm{~K}$ higher ambient temperature. The occurrence $\xi_{\mathrm{t}}$ of the extreme days is set to 1 , since they are used to influence the sizing on the system but not its operational cost.

The analysis of the off-grid dwelling case is based on the system proposed in this paper, with the addition of the following components to the sizing problem:

- A photovoltaic (PV) solar power plant, for a maximum surface of $10 \mathrm{~m}^{2}$

- A heat pump

- A conventional refrigeration system for summer air conditioning

The efficiency of heat pumps and compression refrigeration systems is dependent on the operating temperatures. In this work, we assumed a 50\% exergetic efficiency for these components (Henchoz, 2016), while the COP was calculated according to the following equations:

$$
C O P_{\mathrm{HP}}=\varepsilon \frac{T_{\mathrm{HP}, \text { cond }}}{T_{\mathrm{HP}, \text { cond }}-T_{\mathrm{HP}, \mathrm{evap}}}
$$

$$
C O P_{\mathrm{REF}}=\varepsilon \frac{T_{\mathrm{REF}, \mathrm{evap}}}{T_{\mathrm{REF}, \text { cond }}-T_{\mathrm{REF}, \text { evap }}}
$$

where $\varepsilon$ represents the exergy efficiency and the subscripts HP, $\mathrm{REF}$, cond and evap represent the heat pump, the refrigeration unit, the condenser and the evaporator, respectively. The efficiency of the PV panels was set to 15\% (WES, 2016), referring to polycrystalline cells.

As the performance of the three additional components is influenced by ambient conditions, these had to be defined with the same logic of the typical days. This is represented in Figure 3 (A for the ambient temperature, B for the solar radiation per square meter). These time series were obtained by averaging hourly values for the city of Bologna retrieved from the Dext3r portal for environmental and climate data of the region Emilia Romagna (ARPA, 2018).

It should be noted that in the case of the off-grid dwelling it was assumed to use hydrogen storage tanks at a pressure of 20 bar, which corresponds to the delivery hydrogen pressure of the H-SOFC system used in this study (Pérez-Fortes et al., 2018). Hence, the power demand for the hydrogen compression is already included in the model of the H-SOFC system and the assumption of $\eta_{\mathrm{H}_{2} \text { tank,cha }}=1$ is used. The charging and discharging efficiencies of the battery are assumed constant and equal to 0.88 and 0.93 , respectively (Adametz et al., 2017).

Finally, the price of natural gas $\left(C_{\text {fuel }}\right)$ was fixed to 0.08 EUR/kWh (Eurostat, 2017), and a value of 0.05 was assumed for the interest rate $(i)$.

\subsection{Cruise Ship}

The case study for a cruise ship is based on the work presented in (Baldi et al., 2018), and refers to a small cruise ship (176.9 m long, beam of $28.6 \mathrm{~m}$ ) with a capacity of 1,800 passengers operated in the Baltic Sea. The ship is equipped with several amenities and with a large system for heating, ventilation and air conditioning (HVAC), making its auxiliary energy demand larger and more varied than that of a standard cargo vessel. The ship currently in operations is equipped with a total of eight Diesel engines: four main engines with a power of $5,760 \mathrm{~kW}$ each, and four auxiliary 

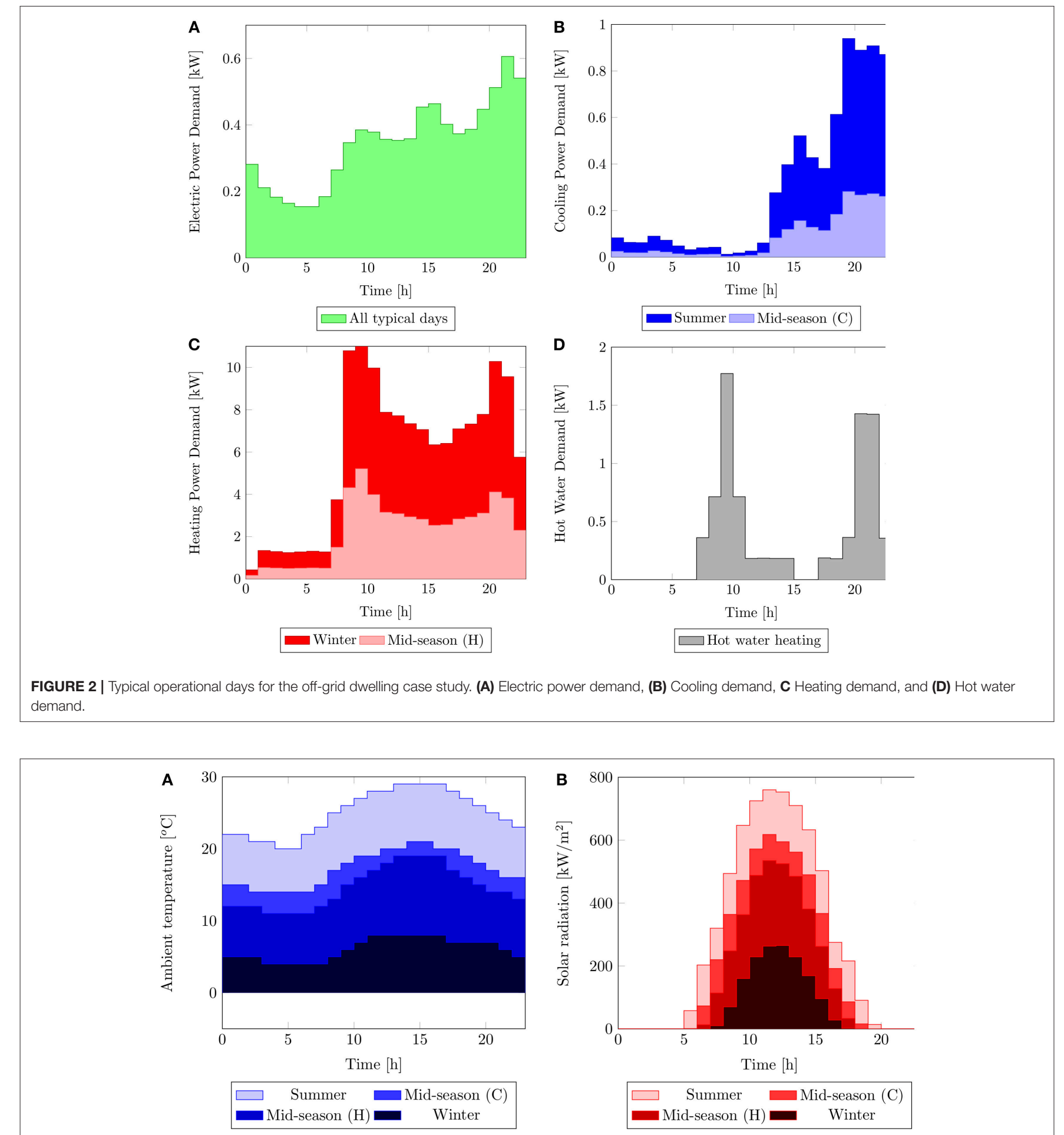

FIGURE 3 | Average ambient conditions for the off-grid dwelling case study. (A) Ambient temperature, (B) Solar radiation (Hence changing "power" to "radiation").

engines for a power of $2,780 \mathrm{~kW}$ each. The heating demand is fulfilled by six heat recovery steam generators (HRSG), located on the exhaust line of the four auxiliary engines and of two of the four main propulsion engines, by a recovery system for the engine cooling waste heat, and by two oil-fired boilers. In this work, we consider a case of a newly built ship of similar size and operational profile.

The energy demand is based on the work proposed in Baldi et al. (2018). We consider for the ship a fully electric system (differently from the current ship, where propulsion and 

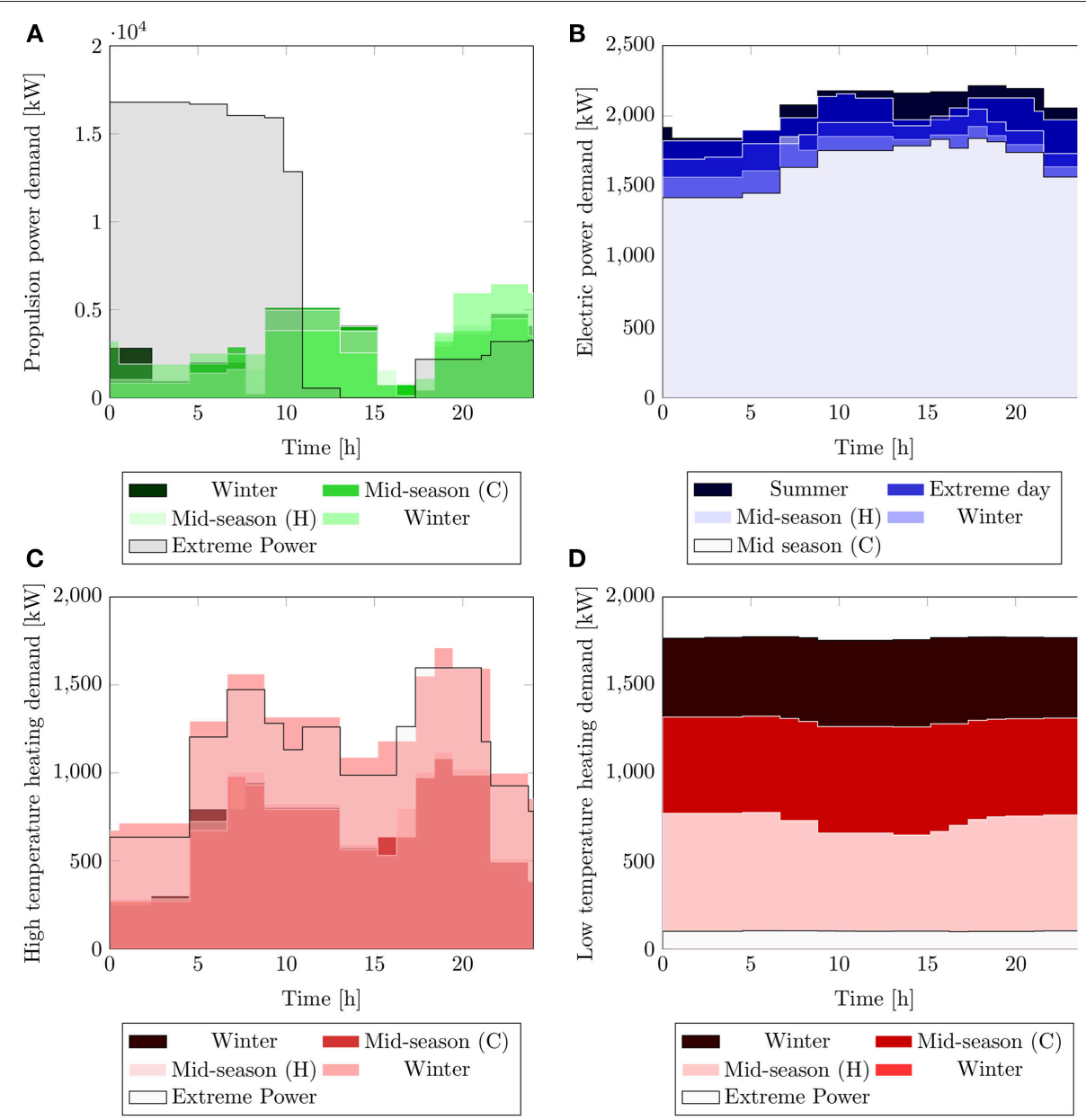

FIGURE 4 | Typical operational days for the cruise ship case study. (A) Propulsion power demand, (B) Electric power demand, (C) High temperature heating demand, (D) Low temperature heating demand.

electrical demand are fulfilled by different systems, but similarly to the majority of cruise ships). The heat demand is assumed to be subdivided in a low-temperature heat demand for air conditioning (from 40 to $60^{\circ} \mathrm{C}$ ) and a high-temperature heat demand for other on board uses (from 70 to $90^{\circ} \mathrm{C}$ ). The demand, originally based on a full year of operations, was clustered as suggested by Fazlollahi et al. (2014) into a total of 5 representative days, one of which being an "extreme day" for the electric power demand, each made of 13 variable-length time steps (see Figure 4):

- Winter $\left(\xi_{1-13}=31\right)$

- Mid-season $(\mathrm{C})\left(\xi_{14-26}=172\right)$

- Mid-season $(\mathrm{H})\left(\xi_{27-39}=112\right)$

- Summer $\left(\xi_{40-52}=41\right)$

- High propulsion demand $\left(\xi_{53-65}=9\right)$

This is justified by the fact that the ship operates on daily cruises, and hence the operational and ambient fluctuations take place with a cycle of the same duration. The four main typical days represent normal ship operations in three different seasons (hence the difference in heat demand), while the extreme day represents high-speed sailing conditions. The demand hence resulting from the clustering of the original dataset into typical days results to be 25.9 GWh for propulsion, 15.5 GWh for electricity, 6.6 GWh for high temperature heat demand and $8.6 \mathrm{GWh}$ for low temperature heat demand.

In the cruise ship case, we assumed that the system can also include the following components:

- A set of high-speed gas engines

- A gas-fired boiler

- An electric motor on the propeller shaft

Modeling of gas engines was based on the data for MTU 16V 4000 M05-N engines (MTU, 2017). This implied the assumption of a constant mechanical efficiency of $35 \%$, plus heat losses to the exhaust gas $\left(27 \%\right.$ of the fuel input, at $\left.300^{\circ} \mathrm{C}\right)$, to the high temperature cooling systems $\left(16 \%, 90^{\circ} \mathrm{C}\right)$ and to the low temperature cooling systems $\left(13 \%\right.$, at $\left.50^{\circ} \mathrm{C}\right)$. The efficiency of the gas boiler is assumed to be equal to 0.85 as a reference value 

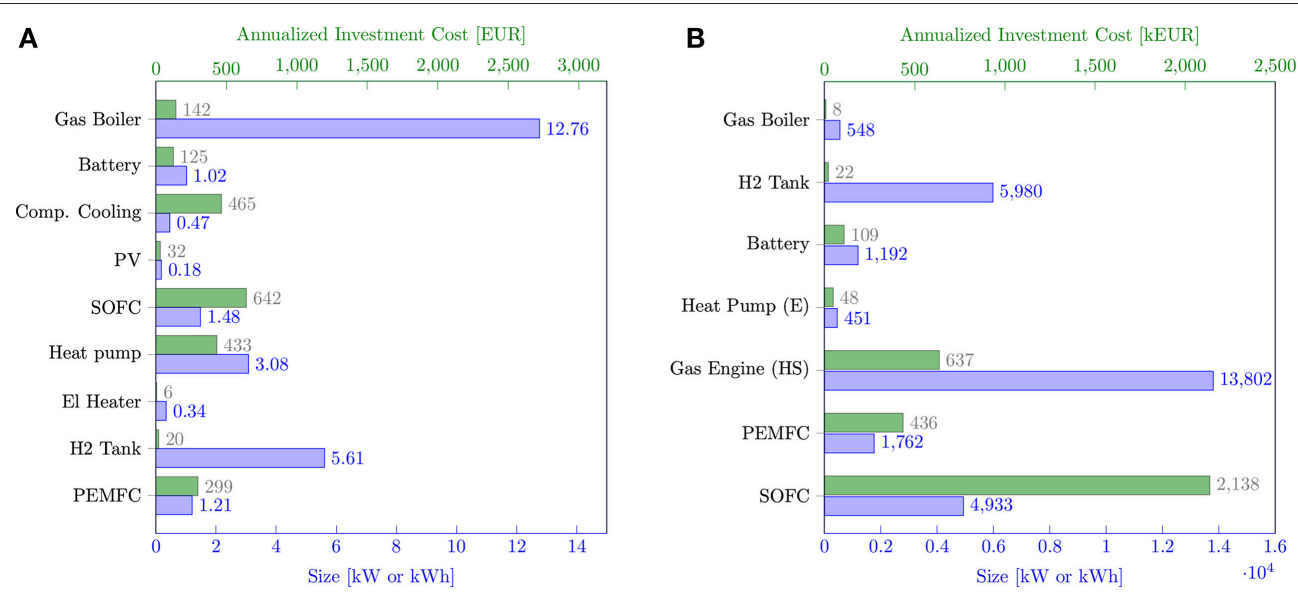

FIGURE 5 | Results of the optimization of the design of the system. (A) Off-grid dwelling, (B) Cruise ship.
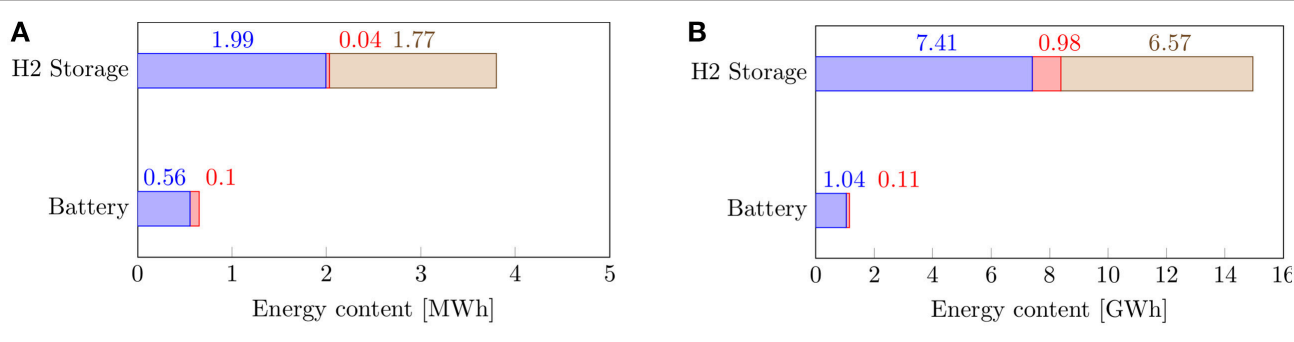

$\square$ Useful output $\square$ Storage losses $\square$ Conversion losses

$\square$ Useful output $\square$ Storage losses $\square$ Conversion losses

FIGURE 6 | Usage and losses of energy storage. (A) Off-grid dwelling, (B) Cruise ship.
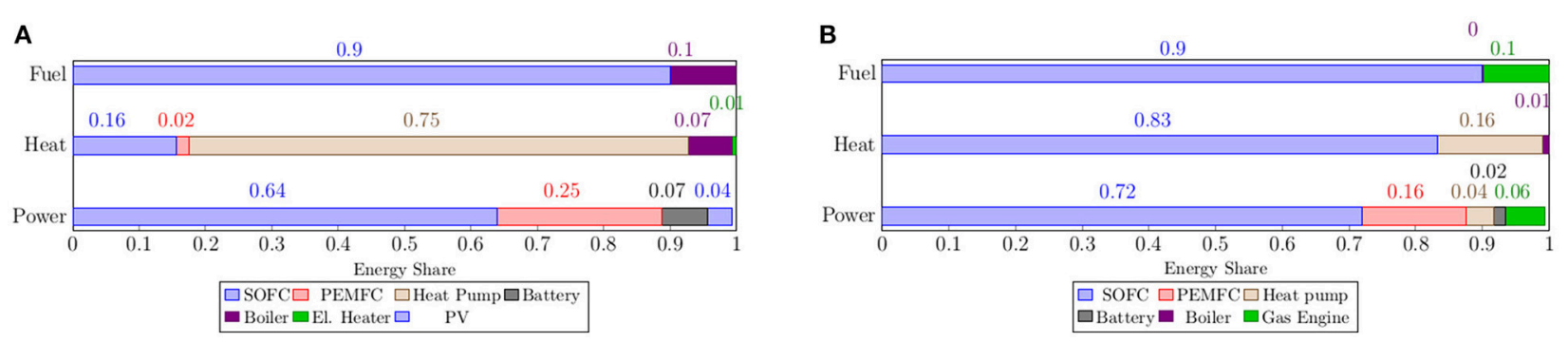

FIGURE 7 | Energy share among different utilities: Power generation, heat generation, fuel consumption. (A) Off-grid dwelling, (B) Cruise ship.

resulting from a compromise of what reported by Cohen et al. [0.83-0.89] (Cohen and Fritz, 1962) and Mrzljak et al. [0.7-0.79] (Mrzljak et al., 2017), with the additional consideration that a natural gas fired boiler allows for a lower outlet temperature of the exhaust gas, and hence works at higher efficiency. The heat flow is modeled as entirely resulting from the cooling of the exhaust gas from 900 to $120^{\circ} \mathrm{C}$.

In the case of the cruise ship, as the available volume for storage is limited, we assumed to use hydrogen storage tanks at 700 bar pressure. To account for the power demand required to compress the hydrogen from 20 to 700 bar we assumed a value of $\eta_{\mathrm{H}_{2} \text { tank,cha }}=0.93$, which results from the assumption of a specific compression work of $2.9 \mathrm{kWh} / \mathrm{kg}_{H_{2}}$ (Gardiner, 2009).
A constant efficiency of 0.95 was assumed for electric motors and generators. The charging and discharging efficiencies of the battery are assumed constant and equal to 0.88 and 0.93 , respectively (Adametz et al., 2017).

Differently from the case of a house, in a ship weight is also a considerable constraint. As fuel cell systems and batteries are known to be heavier than conventional systems of comparable installed power, this has to be taken into account to ensure the feasibility of the system. In this paper, we included this aspect by adding a constraint to the optimization problem, forcing the optimal system not to be heavier than the combined weight of the four Wärtsilä 6L46 main propulsion engines of the current system, weighing 92.7 tons each. 

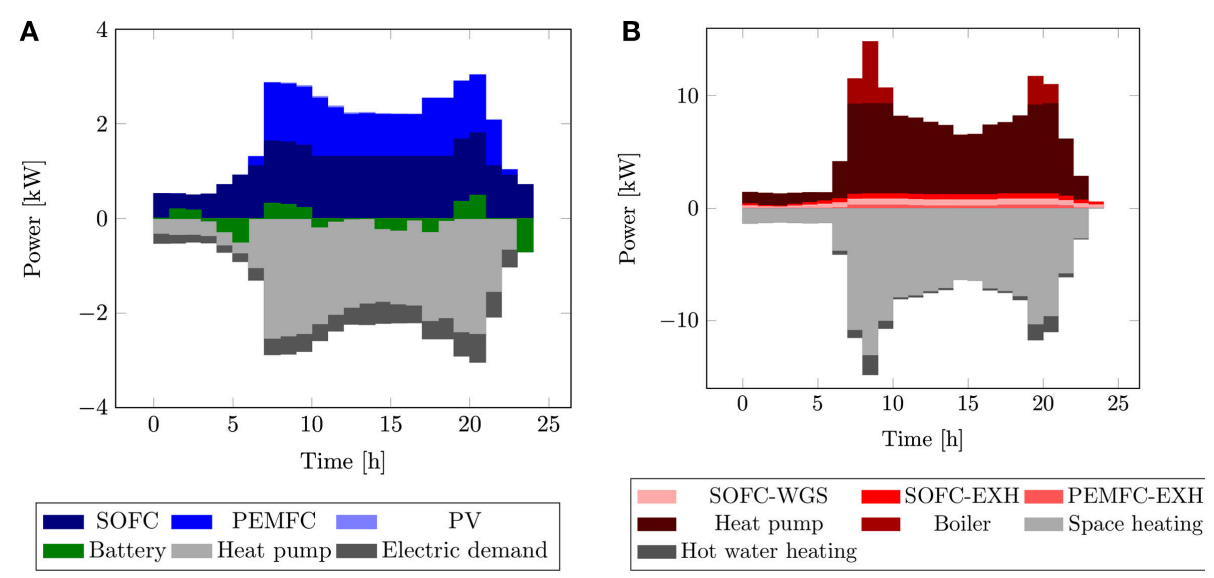

FIGURE 8 | Share of power generation and demand for typical day one, off-grid dwelling case. (A) Power, (B) Heat.
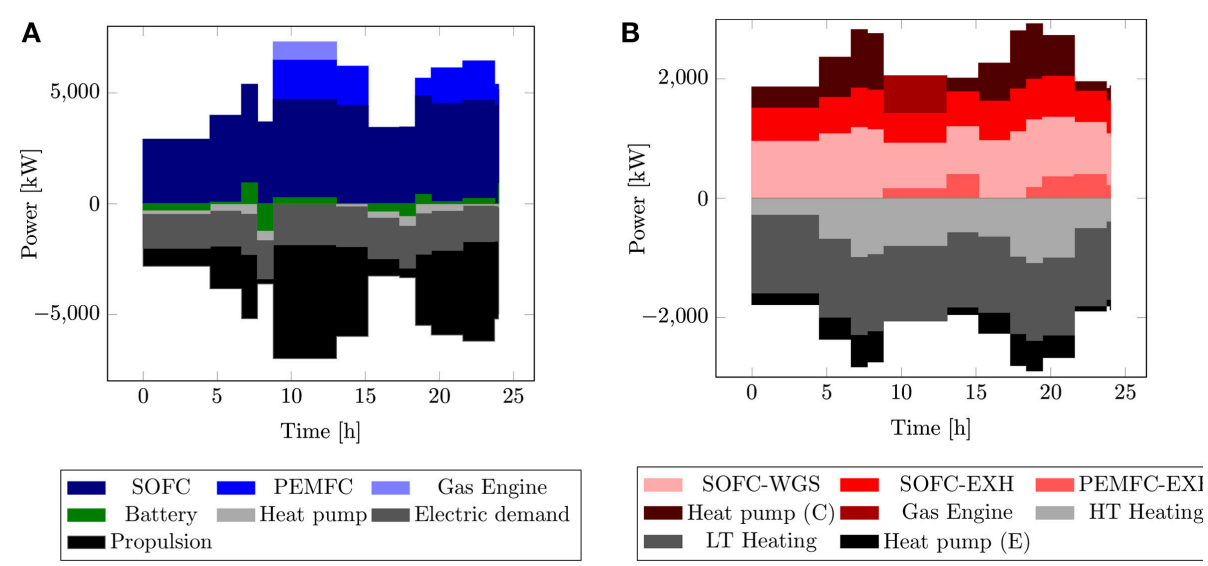

FIGURE 9 | Share of power generation and demand for typical day one, cruise ship case. (A) Power, (B) Heat.

Finally, the price of natural gas $\left(C_{f u e l}\right)$ was fixed to 0.054 EUR/kWh (Danish Maritime Authority, 2012), and a value of 0.05 was assumed for the interest rate $(i)$.

\section{RESULTS}

The results of the application of the proposed hybrid system to the two case studies are reported in Figures 5- 12.

The optimial sizes for the different units in the system are represented in Figure 5. It can be seen that, in both case studies, the SOFC constitutes the largest investment, particularly in the case of the cruise ship. This result suggests that decreasing the specific investment cost of this type of technology will result crucial for their wider adoption. The results of the sizing also highlight the fact that the proposed system, with a combination of a battery and a hydrogen tank, is selected as cost-optimal in both the proposed case studies. This is due to the combination of two, main effects:

- The proposed system allows operating the SOFC at close to constant load, while avoiding excessive use of other, less efficient energy conversion technologies (such as boilers and gas engines)

- The use of storage allows reducing the installed power of the SOFC unit. This has a particularly beneficial effect as, in both systems, the SOFC is the unit with the highest specific investment cost.

This comes however at a cost of higher losses in the storage (see Figure 6). This is due to the lower round-trip efficiency of the energy storage in the form of hydrogen (49-53\% depending on the compression losses), compared to batteries (82\%). This shows, however, that the increase in operational costs due to the higher energy losses is compensated by the lower investment cost. While the cost of batteries is expected to further decrease in the future, it should be noted that the same can be said of the cost of PEMFCs, which represents the largest contribution to the investment cost of the hydrogen storage system.

The results of the yearly energy share are shown in Figure 7. The enforcement of the constraint that $90 \%$ of the total fuel consumed by the system is used by the SOFC can be observed in the first bar for each case study. In the case of the off-grid dwelling, this also translates in a large use of heat pumps for 
the fulfillment of the heat demand, instead of boilers. Figure 7 also highlights the importance of the PEMFC, that is responsible for respectively 25 and $16 \%$ of the total power generation in the system, while batteries are only used to fulfill 7 and $2 \%$ of the demand, respectively. These figures show the importance of the hydrogen plant-PEMFC part of the system, as the system needs to store relatively large amounts of energy over time.

The role of the proposed complementary energy storage technologies of the hybrid system can be seen clearly in Figures 8, 9. The combined energy storage potential of electricity and hydrogen allows for one further degree of freedom in the compromise between high investment costs and operational costs. It can be seen that the PEMFC is used for the largest fluctuations in energy demand and the batteries provide a smaller, but more evenly distributed contribution. The SOFC is, on the other hand, operated at almost constant load.

The importance of the relatively low dynamic performance of SOFCs on the sizing of the energy storage systems is highlighted in Figure 10, where the optimal size of the $\mathrm{H}_{2}$ tank and of the battery is plotted against the maximum load change allowed between two consecutive time steps $\left(\Delta \lambda_{\text {SOFC,max }}\right)$. $\Delta \lambda_{\text {SOFC,max }}=0$ corresponds to forcing the SOFC to operate at constant load, while $\Delta \lambda_{\text {SOFC, } \max }=1$ corresponds to assigning complete freedom to the SOFC unit to adapt to load changes. As can be seen in Figure 10, the installed storage capacity decreases with increasing $\Delta \lambda_{S O F C, \max }$, until a value where they remain substantially constant, thus implying that the proposed hybrid system is beneficial also in light of SOFC technology developments leading to a better dynamic performance. This is achieved for a relatively low value of $\Delta \lambda_{\text {SOFC,max }}$, meaning that, based on the assumptions used in this paper, the major rationale for including the installation of energy storage in the system is related to the reduced cost of the SOFC.

In Figure 11, the advantage of the proposed system in terms of total cost is presented, with respect to a pure SOFC and a SOFC+battery hybrid solution, for both case studies. In both cases, as expected, the total cost of the system increases when possibilities for energy storage are decreased. In the ship-case,

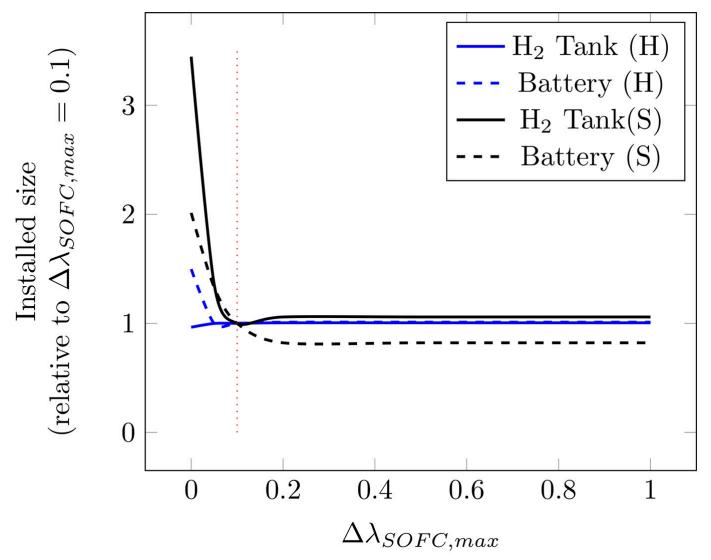

FIGURE 10 | Parametric analysis of the influence of the maximum allowed load change for the SOFC system. the main differences can be identified when the hydrogen storage option is added: in this case the annualized investment cost decrease from 3.9 to 3.4 MEUR, while the yearly operational cost increases from 3.3 to 3.7 , with an overall positive balance on the total cost. It should be noted, however, that in this case it was not possible to satisfy both system constraints (weight and SOFC fuel consumption share) with alternative systems, and hence the SOFC and SOFC+EES cases refers to the optimization solutions obtained with a relaxation of the constraint on the system weight. The off-grid dwelling case seems to show an opposite behavior, with investment cost increasing and operational cost decreasing when more energy storage options are included. This seems to be due to the fact that the use of energy storage allows decreasing the size (and, hence, the cost) of the SOFC, which allows, in turn, a higher investment into more energy efficient technologies, particularly toward heat pumps.

As the proposed system provides benefits in terms of a lower investment cost, at the cost of lower overall efficiency and, hence, higher operational costs, we investigated how the optimal results, both in terms of costs and of component sizes, are influenced by the relative weight assigned to these two, competitive objectives. This is represented in Figure 12. In the off-dwelling case, it can be observed that at high operational costs, it is more convenient to install little storage at all. As the operational cost decreases, the total storage increases, mostly in the form of hydrogen storage, which is cheaper to install. When the operational cost further decreases, the hydrogen storage is gradually substituted by the battery, more expensive to install but also with a higher round-trip efficiency. The trend in the ship case is generally similar, but with some differences. First, in the case of the cruise ship, the presence of storage is needed to respect the weight constraint, and it is not just a way to make the system more efficient. This can be seen from the fact that the size of the storage does not decrease with increasing operational cost in the "low investment cost" area of the Pareto curve. The main tendency in the middle of the operational cost range is the same as observed for the off-grid dwelling, with a progressively decreasing size of the hydrogen storage, accompanied by an increase in the size of the battery, when moving toward the "low operational cost" area. Finally, at the lower limit of the operational cost, the system can only be made more optimal by increasing the size of the SOFC and progressively eliminating the use of high speed Diesel engine as power source for peak demand. This comes however at a high cost, and demands additional storage capacity, as shown by the increasing trend of both battery and hydrogen tank storage capacity.

\section{DISCUSSION}

In this paper, we proposed a system made of an hybrid SOFC, able to generate both power, heat and hydrogen, coupled with a PEMFC, a battery, and a hydrogen storage tank. The proposed system was shown to be economically feasible, and more convenient than alternative options under the constraint that the largest part of the fuel has to be used by the SOFC.

In these conditions, the proposed system is expected to allow overcoming some of the major obstacles to a wider adoption of SOFC on the market. With reference to the cruise ship case 
study, for instance, van Biert et al. (2016) report concerns in the maritime industry related to both dynamic performance, system weight, and cost. All these aspects are addressed in this paper, and promising results are achieved. The advantages of the proposed system, particularly in terms of investment cost and weight, would also prove beneficial in other applications related to the transport sector, such as cars, trucks, and airplanes, where the system's weight constitutes a significant constraint for the design of the power plant.

In the case of stationary applications, such as in the residential case studied in this paper, the main advantage comes from the lower investment cost of the system. While the limitations in the load-following capabilities of the system have not been investigated in previous literature (e.g., both Yang et al. (2014) and Pellegrino et al. (2015) assume no limitations in the dynamic performance of SOFCs), the advantages of using energy storage to reduce the installed size of the SOFC, hence reducing the cost of the system, are known Pellegrino et al. (2015) and Brunaccini et al. (2017). In addition to the advantages it provides to off-grid applications, it should be noted that the proposed system could also provide beneficial in grid-connected systems, in presence of tariff schemes that encourage the usage of micro-CHP plants in self-consumption mode (see, for instance, the FIT auto tariff considered by Pellegrino et al. (2015), where all energy produced and directly consumed by the user is paid $50 \%$ than the energy that is exported to the grid). In this case the possibility of storing energy for later use at a low investment cost is crucial for reducing the payback time of the system, an aspect that makes the system proposed in this paper particularly suitable for these applications.

The work presented in this paper relies on a number of assumptions, whose relevance and impact on the results is hereafter discussed.

Firstly, the results presented for the two case studies show that the benefit of the proposed hybrid system are significantly based on the trade-off between investment and operational costs. Using cost as the objective of the MILP-based optimization of energy systems forces a high degree of uncertainty on the problem (Moret et al., 2017): on the one hand, linear cost functions represent inherently a simplification of a model that is typically non-linear, that is subject to high variability (the price of a component does not only depend on its size) and suffers from a general high uncertainty, particularly in the case of not yet mature technologies. In particular, the recent developments in battery and fuel cell technology, both in relation to price and weight, may modify the optimal balance between hydrogen and electric storage. In addition, energy prices (in this case, the price of natural gas) are subjected to wide fluctuations. The linearization of the problem also prevents from taking into
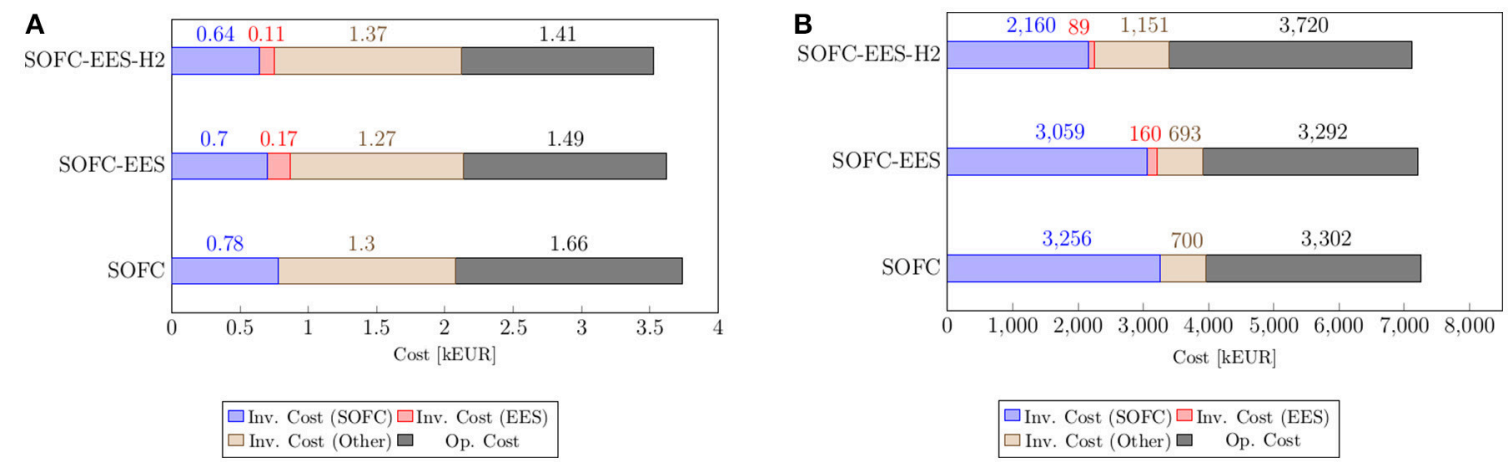

FIGURE 11 | Comparison between the proposed system and alternative SOFC-based systems. (A) Off-grid dwelling case and, (B) Cruise ship case.
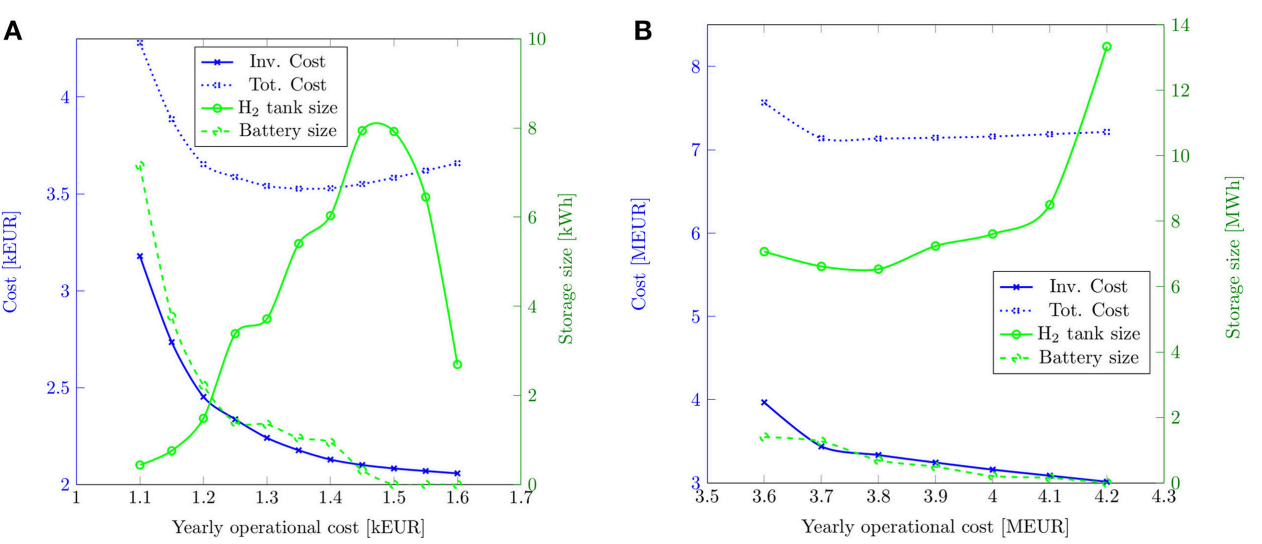

FIGURE 12 | Variation of the annualized investment cost, total yearly cost, and optimal storage sizes for varying yearly operational costs. (A) Off-grid dwelling case and, (B) Cruise ship case. 
account the off-design performance of the installed components. While most of the main components considered in the proposed system maintain a high conversion efficiency over a wide range of operations, this assumption might still lead to inaccurate results in the optimization.

Secondly, as shown in the previous section, the benefits connected to the installation of the system proposed in this paper are partly related to the choice of operating the SOFC close to constant load. While this is today widely accepted as a limitation of the operations of these systems, future technical developments, both in the system control and in material technology, are expected to mitigate this limitation, thus partly reducing the scope of the proposed system. Also the expected reduction in the specific cost of SOFCs may reduce its benefits. It should be noted, however, that the assumption of a specific investment cost of 1,600 EUR/kW for stand-alone SOFCs can be considered as optimistic, hence making the conclusions of this paper durable in time.

From a methodological perspective, the optimization procedure proposed in this paper includes a detailed representation of the expected operational conditions of the systems. This implicitly includes the assumption that the system is perfectly controlled, in such way that the storage is charged and discharged exactly when needed. While recent developments in the control of hybrid systems (see, for instance, Upadhyay and Sharma (2014) for a review on the control of hybrid energy systems, and Enang and Bannister (2017) for a review on the control of hybrid vehicles) show that optimal control strategies can be implemented in hybrid propulsion systems, the challenges of the control of a system with two, competing energy storage systems should be further investigated.

It should be noted that, in this case, we have not taken into account the potential of using heat storage as part of the system. Given the load profiles, this appears a potentially convenient solution particularly for the off-grid dwelling case, where the heating demand dominates the electric demand and is characterized by a high degree of variability during the day (Wakui and Yokoyama, 2014; Yang et al., 2014). The influence of considering heat storage as an additional element of the system should hence be investigated in future work.

It should also be noted that the performance of the polygeneration SOFC unit was based on the optimization results reported in (Pérez-Fortes et al., 2018), in a case where a specific set of operational conditions were used for tailoring the performance on the system to the case under investigation, i.e., a hydrogen refueling station. It can be expected that the system could perform more efficiently, both from an energy and a cost perspective, if its energy integration was optimized for the specific case under study.

\section{CONCLUSION}

In this paper, we presented a hybrid poly-generation system based on a solid oxide fuel cells (SOFC) system capable of producing both electric power and hydrogen, and including the use of combined energy storage systems in the form of electricity and hydrogen, together with a PEMFC. The proposed system is thought for isolated energy systems, where the polygeneration system has to take care of all the energy demand and of its variability, with the aim of reducing the dynamic load on the SOFC and the installed size of the main components.

The results showed that the proposed system can be beneficial from an economic perspective in a variety of cases, and allows achieving a high degree of utilization of the SOFC while reducing the investment cost (when compared to a pure SOFC system) and allowing the use of SOFC at close to constant load, thus enhancing its lifetime. These results were confirmed by the application of the proposed system to two case studies: an off-grid dwelling and a cruise ship. In both cases, the optimization of the sizing of the different system components, under the constraint of the major part of the fuel input to be delivered to the SOFC, led to the choice of a mix of hydrogen and electric storage, in combination with a the installation of a PEMFC.

\section{AUTHOR CONTRIBUTIONS}

FB contributed to the writing of the manuscript and with the optimization of the different systems. MP-F contributed with feedback on the manuscript and with the detailed operational data of the SOFC unit for combined power and hydrogen production. LW contributed to the writing of the introduction and provided feedback on the manuscript. FM provided supervision throughout the process.

\section{FUNDING}

The work of FB is financed by the European Commission with a H2020-MSCA-IF-EF grant (grant number 708288). The work of MP-F was developed under the EU H2020 CH2P project. The project has received funding from the Fuel Cells and Hydrogen 2 Joint Undertaking under grant agreement No 735692. The Joint Undertaking receives support from the EU H2020 program, from Hydrogen Europe and Hydrogen Europe Research. Swiss partners receive funding from the State Secretariat of Education, Research and Innovation (SEFRI), contract 16.0223.

\section{ACKNOWLEDGMENTS}

We would like to thank Antti Pohjoranta from VTT for the fruitful discussions about the practical implications of the use of fuel cells on board of ships.

\section{SUPPLEMENTARY MATERIAL}

The Supplementary Material for this article can be found online at: https://www.frontiersin.org/articles/10.3389/fenrg. 2018.00139/full\#supplementary-material

Datasheet 1 | Input data for energy demand and ambient conditions for case study 1 (off-grid dwelling).

Datasheet 2 | Input data for energy demand and ambient conditions for case study 2 (cruise ship). 


\section{REFERENCES}

Adametz, P., Pötzinger, C., Müller, S., Müller, K., Preißinger, M., Lechner, R., et al. (2017). Thermodynamic evaluation and carbon footprint analysis of the application of hydrogen-based energy-storage systems in residential buildings. Ener. Technol. 5, 495-509. doi: 10.1002/ente.201600388

Aguiar, P., Brett, D., and Brandon, N. (2007). Feasibility study and technoeconomic analysis of an SOFC/battery hybrid system for vehicle applications. J. Power Sour. 171, 186-197. doi: 10.1016/j.jpowsour.2006.12.049

Al-Sharafi, A., Sahin, A. Z., Ayar, T., and Yilbas, B. S. (2017). Techno-economic analysis and optimization of solar and wind energy systems for power generation and hydrogen production in Saudi Arabia. Renew. Sustain. Ener. Rev. 69, 33-49. doi: 10.1016/j.rser.2016.11.157

ARPA (2018). Dext3r. Available online at: http://www.smr.arpa.emr.it/dext3r/ (Accessed July 03, 2018).

Arsalis, A., Nielsen, M. P., and Kær, S. K. (2011). Modeling and off-design performance of a $1 \mathrm{kWe}$ HT-PEMFC (high temperature-proton exchange membrane fuel cell)-based residential micro-CHP (combined-heat-andpower) system for Danish single-family households. Energy 36, 993-1002. doi: 10.1016/j.energy.2010.12.009

Bae, Y., Lee, S., Yoon, K. J., Lee, J.-H., and Hong, J. (2018). Threedimensional dynamic modeling and transport analysis of solid oxide fuel cells under electrical load change. Energ. Convers. Manage. 165, 405-418. doi: 10.1016/j.enconman.2018.03.064

Baldi, F., Ahlgren, F., Nguyen, T. V., Thern, M., and Andersson, K. (2018). Energy and exergy analysis of a cruise ship. Energies 11:2508. doi: 10.3390/en11102508

Becker, W. L., Braun, R. J., Penev, M., and Melaina, M. (2012). Design and technoeconomic performance analysis of a $1 \mathrm{MW}$ solid oxide fuel cell polygeneration system for combined production of heat, hydrogen, and power. J. Power Sour. 200, 34-44. doi: 10.1016/j.jpowsour.2011.10.040

Bianchi, M., Branchini, L., Ferrari, C., and Melino, F. (2014). Optimal sizing of grid-independent hybrid photovoltaic-battery power systems for household sector. Appl. Ener. 136, 805-816. doi: 10.1016/j.apenergy.2014.07.058

Bianchi, M., De Pascale, A., and Melino, F. (2013). Performance analysis of an integrated CHP system with thermal and Electric Energy Storage for residential application. Appl. Ener. 112, 928-938. doi: 10.1016/j.apenergy.2013.01.088

BMI (2016). Manufacturing Cost Analysis of 100 and $250 \mathrm{kw}$ Fuel Cell Systems for Primary Power and Combined Heat and Power Applications. Technical report, Batelle Memorial Institute.

Bossel, U. (2015). Small scale power generation for road trucks with Planar SOFC System. ECS Trans. 68, 193-199. doi: 10.1149/06801.0193

Brunaccini, G., Sergi, F., Aloisio, D., Ferraro, M., Blesznowski, M., Kupecki, J., et al. (2017). Modeling of a SOFC-HT battery hybrid system for optimal design of off-grid base transceiver station. Int. J. Hydrog. Ener. 42, 27962-27978. doi: 10.1016/j.ijhydene.2017.09.062

Bujalski, W., Dikwal, C., and Kendall, K. (2007). Cycling of three solid oxide fuel cell types. J. Power Sour. 171, 96-100. doi: 10.1016/j.jpowsour.2007.01.029

Buonomano, A., Calise, F., d' Accadia, M. D., Palombo, A., and Vicidomini, M. (2015). Hybrid solid oxide fuel cells-gas turbine systems for combined heat and power: a review. Appl. Ener. 156, 32-85. doi: 10.1016/j.apenergy.2015.06.027

Cohen, L. and Fritz, W. (1962). Efficiency determination of marine boilers: input-output versus heat-loss method. J. Eng. Power 84, 39-43. doi: $10.1115 / 1.3673375$

Cozzolino, R., Lombardi, L., and Tribioli, L. (2017). Use of biogas from biowaste in a solid oxide fuel cell stack: Application to an off-grid power plant. Renew. Ener. 111, 781-791. doi: 10.1016/j.renene.2017.04.027

Danish Maritime Authority (2012). North European LNG Infrastructure Project. Eu report, Danish Maritime Authority.

Das, T., and Snyder, S. (2013). Adaptive control of a solid oxide fuel cell ultracapacitor hybrid system. IEEE Trans. Control Syst. Technol. 21, 372-383. doi: 10.1109/TCST.2011.2181514

Dhingra, H., and Peppley, B. (2013). Sensitivity analysis of a $1 \mathrm{~kW}$ diesel-fuelled SOFC generator: a single and paired-variable study. J. Power Sour. 239, 527537. doi: 10.1016/j.jpowsour.2013.03.107

Dicks, A. L., Fellows, R. G., Martin Mescal, C., and Seymour, C. (2000). A study of SOFC-PEM hybrid systems. J. Power Sour. 86, 501-506. doi: 10.1016/S0378-7753(99)00492-9
Dimitrova, Z. and Maréchal, F. (2017). Environomic design for electric vehicles with an integrated solid oxide fuel cell (SOFC) unit as a range extender. Renew. Ener. 112, 124-142. doi: 10.1016/j.renene.2017.05.031

Dunn, B., Kamath, H., and Tarascon, J.-M. (2011). Electrical energy storage for the grid: a battery of choices. Science 334, 928-935. doi: 10.1126/science.1212741

Enang, W. and Bannister, C. (2017). Modelling and control of hybrid electric vehicles (A comprehensive review). Renew. Sustain. Ener. Rev. 74, 1210-1239. doi: 10.1016/j.rser.2017.01.075

Eurostat (2017). Gas Prices for Household Consumers - Bi-annual Data (from 2007 onwards). Available online at: http://appsso.eurostat.ec.europa.eu/nui/ submitViewTableAction.do (Accessed July 31, 2018).

Fardadi, M., McLarty, D. F., and Jabbari, F. (2016). Investigation of thermal control for different sofc flow geometries. Appl. Ener. 178, 43-55. doi: 10.1016/j.apenergy.2016.06.015

Fazlollahi, S., Bungener, S. L., Mandel, P., Becker, G., and Maréchal, F. (2014). Multi-objectives, multi-period optimization of district energy systems: I. Selection of typical operating periods. Comput. Chem. Eng. 65, 54-66. doi: 10.1016/j.compchemeng.2014.03.005

Gardiner, M. (2009). Energy Requirements for Hydrogen Gas Compression and Liquefaction as Related to Vehicle Storage Needs. Technical Report 9013, Department of Energy.

Gür, T. M. (2016). Comprehensive review of methane conversion in solid oxide fuel cells: prospects for efficient electricity generation from natural gas. Prog. Ener. Combus. Sci. 54, 1-64. doi: 10.1016/j.pecs.2015.10.004

Hawkes, A. D., Brett, D. J. L., and Brandon, N. P. (2009). Fuel cell micro-CHP techno-economics: Part 2 - Model application to consider the economic and environmental impact of stack degradation. Int. J. Hydrog. Ener. 34, 9558-9569. doi: 10.1016/j.ijhydene.2009.09.095

Hemmes, K., Patil, A., and Woudstra, N. (2008). Flexible coproduction of hydrogen and power using internal reforming solid oxide fuel cells system. $J$. Fuel Cell Sci. Technol. 5:041010. doi: 10.1115/1.2931459

Henchoz, S. (2016). Potential of Refrigerant Based District Heating and Cooling Networks. Ph.D. thesis, EPFL, Lausanne.

IEA (2017). World Energy Outlook 2017. OECD Publishing, International Energy Agency.

Jacobsen, L. T., Spivey, B. J., and Hedengren, J. D. (2013). "Model predictive control with a rigorous model of a Solid Oxide fuel cell," in 2013 American Control Conference (Washington, DC), 3741-3746. doi: 10.1109/ACC.2013.6580409

Jia, Z., Sun, J., Dobbs, H., and King, J. (2015). Feasibility study of solid oxide fuel cell engines integrated with sprinter gas turbines: modeling, design and control. J. Power Sour. 275, 111-125. doi: 10.1016/j.jpowsour.2014.10.203

Kotas, T. J. (2013). The Exergy Method of Thermal Plant Analysis. London: Butterworths.

Leal, E. M., and Brouwer, J. (2005). A Thermodynamic analysis of electricity and hydrogen co-production using a solid oxide fuel cell. J. Fuel Cell Sci. Technol. 3, 137-143. doi: 10.1115/1.2173669

Linhoff, B., Townsend, D., Boland, D., Hewitt, G., Thomas, B., Gut, A., and Marsland, R. (1982). User Guide on Process Integration for the Efficient Use of Energy. Rugby: The Institution of Chemical Engineers.

Mandelli, S., Barbieri, J., Mereu, R., and Colombo, E. (2016). Off-grid systems for rural electrification in developing countries: definitions, classification and a comprehensive literature review. Renew. Sustain. Ener. Rev. 58, 1621-1646. doi: 10.1016/j.rser.2015.12.338

Mian, A., Martelli, E., and Maréchal, F. (2016). Framework for the multiperiod sequential synthesis of heat exchanger networks with selection, design, and scheduling of multiple utilities. Indus. Eng. Chem. Res. 55, 168-186. doi: 10.1021/acs.iecr.5b02104

Moret, S., Gironès, V. C., Bierlaire, M., and Maréchal, F. (2017). Characterization of input uncertainties in strategic energy planning models. Appl. Ener. 202, 597-617. doi: 10.1016/j.apenergy.2017.05.106

Mrzljak, V., Poljak, I., and Medica-Viola, V. (2017). Dual fuel consumption and efficiency of marine steam generators for the propulsion of $\ln g$ carrier. Appl. Thermal Eng. 119, 331-346. doi: 10.1016/j.applthermaleng.2017. 03.078

MTU (2017). Gas Engine Series 4000 m05-n for Vessels With Unrestricted Continuous Operation (1a) (Datasheet). 
Mueller, F., Jabbari, F., Gaynor, R., and Brouwer, J. (2007). Novel solid oxide fuel cell system controller for rapid load following. J. Power Sour. 172, 308-323. doi: 10.1016/j.jpowsour.2007.05.092

Nakajo, A., Mueller, F., Brouwer, J., Van herle, J., and Favrat, D. (2012a). Mechanical reliability and durability of SOFC stacks. Part I :modelling of the effect of operating conditions and design alternatives on the reliability. Int. J. Hydrog. Ener. 37, 9249-9268. doi: 10.1016/j.ijhydene.2012.03.043

Nakajo, A., Mueller, F., Brouwer, J., Van herle, J., and Favrat, D. (2012b). Mechanical reliability and durability of SOFC stacks. Part II: modelling of mechanical failures during ageing and cycling. Int. J. Hydrog. Ener. 37, 92699286. doi: 10.1016/j.ijhydene.2012.03.023

NERA and AEA (2009). The UK Supply Curve for Renewable Heat, Study for the Department of Energy and Climate Change. DECC.

Nguyen, G., Sahlin, S., Andreasen, S. J., Shaffer, B., and Brouwer, J. (2016). Dynamic modeling and experimental investigation of a high temperature PEM fuel cell stack. Int. J. Hydrog. Ener. 41, 4729-4739. doi: 10.1016/j.ijhydene.2016.01.045

Nykvist, B., and Nilsson, M. (2015). Rapidly falling costs of battery packs for electric vehicles. Nat. Clim. Change 5:329. doi: 10.1038/nclimate2564

Obara, S. (2010). Power generation efficiency of an SOFC-PEFC combined system with time shift utilization of SOFC exhaust heat. Int. J. Hydrog. Ener. 35, 757-767. doi: 10.1016/j.ijhydene.2009.11.032

Pellegrino, S., Lanzini, A., and Leone, P. (2015). Techno-economic and policy requirements for the market-entry of the fuel cell microCHP system in the residential sector. Appl. Ener. 143, 370-382. doi: 10.1016/j.apenergy.2015.01.007

Perdikaris, N., Panopoulos, K. D., Hofmann, P., Spyrakis, S., and Kakaras, E. (2010). Design and exergetic analysis of a novel carbon free tri-generation system for hydrogen, power and heat production from natural gas, based on combined solid oxide fuel and electrolyser cells. Int. J. Hydrog. Ener. 35, 2446-2456. doi: 10.1016/j.ijhydene.2009.07.084

Pérez-Fortes, M., Mian, A., Diethelm, S., Wang, L., Maréchal, F., Van Herle, J., Santhanam, S., et al. (2018). "Process optimization of a sofc system for the combined production of hydrogen and electricity," in Proceedings of the 13th European SOFC and SOE Forum 2018 (Lucerne).

Protonex (2015). Protonex early access to new propane SOFC remote power system. Fuel Cells Bull. 2015:7. doi: 10.1016/S1464-2859(15)30050-X

Rager, J. (2015). Urban Energy System Design from the Heat Perspective Using Mathematical Programming Including Thermal Storage. Ph.D. thesis, École Polytechnique Fédérale de Lausanne.

Romeo, G., Cestino, E., and Borello, F. (2012). "More/all electric aicraft based on fuel cell energy system: the ENFICA-FC experience," in 28th Congress of the Internation Council of the Aeronautical Sciences (Brisbane, QLD).

Santarelli, M., Cabrera, M., and Calí, M. (2010). Solid oxide fuel based auxiliary power unit for regional jets: Design and mission simulation with different cell geometries. J. Fuel Cell Sci. Technol. 7, 0210061-02100611. doi: $10.1115 / 1.3176282$

Shaffer, B. and Brouwer, J. (2014). Feasibility of solid oxide fuel cell dynamic hydrogen coproduction to meet building demand. J. Power Sour. 248, 58-69. doi: 10.1016/j.jpowsour.2013.08.144

SOLIDpower (2017). SOLIDpower expands production capacity, SOFC runtime record. Fuel Cells Bull. 2017:9. doi: 10.1016/S1464-2859(17)30421-2

Subramanyan, K., Diwekar, U. M., and Goyal, A. (2004). Multi-objective optimization for hybrid fuel cells power system under uncertainty. J. Power Sour. 132, 99-112. doi: 10.1016/j.jpowsour.2003.12.053

Suciu, R., Girardin, L., and Maréchal, F. (2018). Energy integration of CO2 networks and power to gas for emerging energy autonomous cities in Europe. Energy 157, 830-842. doi: 10.1016/j.energy.2018.05.083

Tan, L., Yang, C., and Zhou, N. (2016). Performance of the solid oxide fuel cell (SOFC)/proton-exchange membrane fuel cell (PEMFC) hybrid system. Chem. Eng. Technol. 39, 689-698. doi: 10.1002/ceat.201500424

Trivyza, N. L., Rentizelas, A., and Theotokatos, G. (2018). A novel multiobjective decision support method for ship energy systems synthesis to enhance sustainability. Ener. Convers. Manage. 168, 128-149. doi: 10.1016/j.enconman.2018.04.020
Tse, L. K. C., Wilkins, S., McGlashan, N., Urban, B., and Martinez-Botas, R. (2011). Solid oxide fuel cell/gas turbine trigeneration system for marine applications. J. Power Sour. 196, 3149-3162. doi: 10.1016/j.jpowsour.2010. 11.099

Tu, H., and Stimming, U. (2004). Advances, aging mechanisms and lifetime in solid-oxide fuel cells. J. Power Sour. 127, 284-293. doi: 10.1016/j.jpowsour.2003.09.025

Upadhyay, S., and Sharma, M. (2014). A review on configurations, control and sizing methodologies of hybrid energy systems. Renew. Sustain. Ener. Rev. 38, 47-63. doi: 10.1016/j.rser.2014.05.057

van Biert, L., Godjevac, M., Visser, K., and Aravind, P. (2016). A review of fuel cell systems for maritime applications. J. Power Sour. 327, 345-364. doi: 10.1016/j.jpowsour.2016.07.007

Van Herle, J., Membrez, Y., and Bucheli, O. (2004). Biogas as a fuel source for SOFC co-generators. J. Power Sour. 127, 300-312. doi: 10.1016/j.jpowsour.2003.09.027

Vollmar, H.-E., Maier, C.-U., Nölscher, C., Merklein, T., and Poppinger, M. (2000). Innovative concepts for the coproduction of electricity and syngas with solid oxide fuel cells. J. Power Sour. 86, 90-97. doi: 10.1016/S0378-7753(99)00421-8

Wachsman, E., Marlowe, C., and Lee, K. (2012). Role of solid oxide fuel cells in a balanced energy strategy. Ener. Environ. Sci. 5, 5498-5509. doi: 10.1039/C1EE02445K

Wakui, T., and Yokoyama, R. (2014). Optimal structural design of residential cogeneration systems in consideration of their operating restrictions. Energy 64, 719-733. doi: 10.1016/j.energy.2013.10.002

WES (2016). Solar 2016. Technical report, World Energy Council.

Wu, X., and Gao, D. (2017). Fault tolerance control of sofc systems based on nonlinear model predictive control. Int. J. Hydrog. Ener. 42, 2288-2308. doi: 10.1016/j.ijhydene.2016.09.203

Yang, J., Qin, S., Zhang, W., Ding, T., Zhou, B., Li, X., and Jian, L. (2017) Improving the load-following capability of a solid oxide fuel cell system through the use of time delay control. Int. J. Hydrog. Ener. 42, 1221-1236. doi: 10.1016/j.ijhydene.2016.10.107

Yang, W., Zhao, Y., Liso, V., and Brandon, N. (2014). Optimal design and operation of a syngas-fuelled SOFC micro-CHP system for residential applications in different climate zones in China. Ener. Build. 80, 613-622. doi: 10.1016/j.enbuild.2014.05.015

Yokokawa, H., Tu, H., Iwanschitz, B., and Mai, A. (2008). Fundamental mechanisms limiting solid oxide fuel cell durability. J. Power Sour. 182, 400412. doi: 10.1016/j.jpowsour.2008.02.016

Yokoo, M., and Take, T. (2004). Simulation analysis of a system combining solid oxide and polymer electrolyte fuel cells. J. Power Sour. 137, 206-215. doi: 10.1016/j.jpowsour.2004.06.007

Yokoo, M., Watanabe, K., Arakawa, M., and Yamazaki, Y. (2006). The effect of fuel feeding method on performance of SOFC-PEFC system. J. Power Sour. 159, 836-845. doi: 10.1016/j.jpowsour.2005.11.093

Yokoo, M., Watanabe, K., Arakawa, M., and Yamazaki, Y. (2007). Influence of current densities in SOFC and PEFC stacks on a SOFC-PEFC combined system. J. Power Sour. 163, 892-899. doi: 10.1016/j.jpowsour.2006.09.050

Zhang, X., Chan, S., Li, G., Ho, H., Li, J., and Feng, Z. (2010). A review of integration strategies for solid oxide fuel cells. J. Power Sour. 195, 685-702. doi: 10.1016/j.jpowsour.2009.07.045

Conflict of Interest Statement: The authors declare that the research was conducted in the absence of any commercial or financial relationships that could be construed as a potential conflict of interest.

Copyright (c) 2019 Baldi, Wang, Pérez-Fortes and Maréchal. This is an open-access article distributed under the terms of the Creative Commons Attribution License (CC BY). The use, distribution or reproduction in other forums is permitted, provided the original author(s) and the copyright owner(s) are credited and that the original publication in this journal is cited, in accordance with accepted academic practice. No use, distribution or reproduction is permitted which does not comply with these terms. 


\section{A. NOMENCLATURE}

\begin{tabular}{|c|c|}
\hline \multicolumn{2}{|c|}{ Acronyms } \\
\hline GT & Gas turbine \\
\hline $\mathrm{HP}$ & Heat pump \\
\hline HRSG & Heat recovery steam generator \\
\hline HVAC & Heating, ventilation and air conditioning \\
\hline ICE & Internal combustion engine \\
\hline MILP & Mixed integer linear programming \\
\hline PEMFC & Proton exchange membrane fuel cell \\
\hline PV & Photovoltaic \\
\hline REF & Refrigeration unit \\
\hline SOFC & Solid oxide fuel cell \\
\hline \multicolumn{2}{|l|}{ Indices } \\
\hline$k$ & Temperature interval in the heat cascade \\
\hline 1 & Type of energy/material flow \\
\hline$p$ & Process \\
\hline$t$ & Time step \\
\hline$u$ & Utility \\
\hline \multicolumn{2}{|c|}{ Parameters } \\
\hline$\Delta t(t)$ & Duration of the time step $t[\mathrm{~h}]$ \\
\hline$\dot{E}_{\mid, \mathrm{u}}^{\max }$ & Maximum net flow of energy/material flow / for utility $u[\mathrm{~kW}]$ \\
\hline$\dot{E}_{l, p, t}$ & Energy/material flow / for process $p$ at time step $t[\mathrm{~kW}]$ \\
\hline$\varepsilon$ & Exergy efficiency $[-]$ \\
\hline$\xi_{\mathrm{t}}$ & $\begin{array}{l}\text { Number of occurrences of the time step } t \text { in a representative } \\
\text { year [-] }\end{array}$ \\
\hline$\xi_{\mathrm{t}}$ & Yearly occurrence of the time step t [-] \\
\hline$C_{\text {inv,fix }}(u)$ & Fixed investment cost of utility $u$ [EUR] \\
\hline$C_{\text {inv,var }}(u)$ & $\begin{array}{l}\text { Size-dependent investment cost of utility } u \text { [EUR/kW or } \\
\text { EUR/kWh] }\end{array}$ \\
\hline$C_{\text {fuel }}$ & Fuel cost [EUR/kWh] \\
\hline$i$ & Interest rate [-] \\
\hline$T_{\mathrm{HP}, \text { cond }}$ & $\begin{array}{l}\text { Temperature of the working fluid in the condenser of the } \\
\text { refrigeration unit }[\mathrm{K}]\end{array}$ \\
\hline$T_{\text {HP,evap }}$ & $\begin{array}{l}\text { Temperature of the working fluid in the evaporator of the } \\
\text { refrigeration unit }[\mathrm{K}]\end{array}$ \\
\hline$T_{\mathrm{REF}, \mathrm{cond}}$ & $\begin{array}{l}\text { Temperature of the working fluid in the condenser of the heat } \\
\text { pump }[\mathrm{K}]\end{array}$ \\
\hline$T_{\text {REF,evap }}$ & $\begin{array}{l}\text { Temperature of the working fluid in the evaporator of the heat } \\
\text { pump }[\mathrm{K}]\end{array}$ \\
\hline$N_{y}(u)$ & Lifetime of utility $u[y]$ \\
\hline \multicolumn{2}{|l|}{ Variables } \\
\hline$C_{\text {inv, act }}$ & Annualized investment cost [EUR/y] \\
\hline$C_{\mathrm{op}}$ & Yearly operational cost [EUR/y] \\
\hline$f_{\mathrm{u}, \mathrm{t}}^{\prime}$ & Load of utility $u$ at time step $t[-]$ \\
\hline$f_{\text {obj }}$ & Objective function [EUR/y] \\
\hline$f_{\mathrm{u}}$ & Installed size of utility $u$, relative to its maximum size [-] \\
\hline$y_{\mathrm{u}, \mathrm{t}}^{\prime}$ & On-off status of utility $u$ at time step $t[-]$ \\
\hline$y_{\mathrm{u}}$ & Installation decision of utility $u[-]$ \\
\hline
\end{tabular}

\section{B. COMPONENT COST FACTORS}

The cost of the hybrid SOFC was determined based on the estimations proposed by Becker et al. (2012), using the following equation for the component scaling:

$$
C_{i n v}=C_{i n v, 0}\left(\frac{S}{S_{0}}\right)^{n}\left(\frac{\mathrm{CEPCI}}{\mathrm{CEPCI}_{0}}\right) \mathrm{IF}
$$

where the values of all cost parameters apart from the SOFC itself are taken from what reported by Becker et al. (2012). It should be noted that in the system proposed by Becker et al. (2012) the cost is estimated for a unit where the hydrogen is purified using an electrochemical hydrogen separation (EHS) unit. Since we could not find more data specifically related to the cost of a PSA unit, we assumed that the differential between the two does not have an impact on the problem that is higher than the existing uncertainty of the cost functions employed. The specific investment cost for the SOFC was based on the estimations provided in (BMI, 2016), leading to an assumption of $1,060 \mathrm{EUR} / \mathrm{kW}$ installed (based on 10,000 units/year production volume and $250 \mathrm{~kW}$ system). This led to the assumption of a total cost of the SOFC-based system of 2,200 EUR per $\mathrm{kW}$ of electric power installed.

The investment cost of the PEMFC was also estimated based on (BMI, 2016) and led to an assumption of 1,600 EUR per kW of installed power, based on 10,000 units/year production volume and on a $250 \mathrm{~kW}$ system. A cost of $247 \mathrm{EUR} / \mathrm{m}^{2}$ was used for PV panels, based on Suciu et al. (2018).

The investment cost of batteries was set to $300 \mathrm{EUR} / \mathrm{kWh}$ based on the work of Nykvist and Nilsson (2015), who estimated in 2014 that battery prices for electric vehicles were expected to drop to $230 \mathrm{USD} / \mathrm{kWh}$ by 2017-2018. The fact that the reported estimated was largely based on market leaders, such as Tesla and Nissan, led us to use a more conservative cost factor. The investment cost of the hydrogen storage system was set to 45 $\mathrm{EUR} / \mathrm{kWh}$, based on the value of $1500 \mathrm{USD} / \mathrm{kg}$ reported by Al-Sharafi et al. (2017) following unit conversion.

The investment cost of gas boilers, heat pumps and refrigeration units is taken from NERA and AEA (2009). Prices referred to small residential applications are taken for the off-grid dwelling case, while prices for industrial units are considered for the cruise ship case.

Traditional components are assigned a lifetime of 20 years, while the SOFC systems are assigned a lifetime of 6 years, based on 50,000 h of operations and on a use of roughly 8,000 $\mathrm{h} /$ year, as the SOFC is responsible for the base-load of the ship and hence operated continuously. We assumed a 8-year lifetime for the PEMFC. Despite the general expected lower duration of PEMFCs compared to SOFCs, the PEMFC is not expected to be used continuously in the proposed system configuration. The assumption is based on an operational life of $30,000 \mathrm{~h}$ and on $4,000 \mathrm{~h}$ of operations per year. It should be noted that these assumptions can be considered as conservative, as in real applications only the fuel stacks, and not the full system, would be replaced. 